H A R VAR D

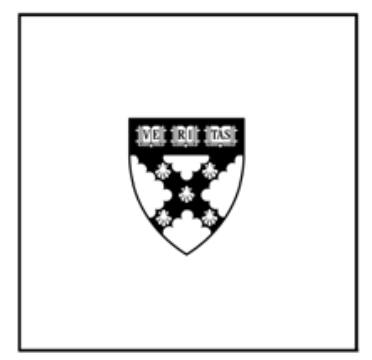

\title{
Quality Management and Job Quality: How the ISO 9001 Standard for Quality Management Systems Affects Employees and Employers
}

David I. Levine

Michael W. Toffel

\section{Working Paper}

09-018 


\title{
Quality Management and Job Quality: How the ISO 9001 Standard for Quality Management Systems Affects Employees and Employers
}

\author{
David I. Levine \\ Haas School of Business, University of California, Berkeley, CA 94720, levine@ haas.berkeley.edu \\ Michael W. Toffel ${ }^{*}$ \\ Harvard Business School, Boston, MA 02163, mtoffel@hbs.edu
}

January 18, 2010

Forthcoming in Management Science

\begin{abstract}
Several studies have examined how the ISO 9001 Quality Management System standard predicts changes in organizational outcomes such as profits. This is the first large-scale study to explore how employee outcomes such as employment, earnings, and health and safety change when employers adopt ISO 9001. We analyzed a matched sample of nearly 1,000 companies in California. ISO 9001 adopters subsequently had far lower organizational death rates than a matched control group of non-adopters. Among surviving employers, ISO adopters had higher growth rates for sales, employment, payroll, and average annual earnings. Injury rates declined slightly for ISO 9001 adopters, although total injury costs did not. These results have implications for organizational theory, managers, and public policy.
\end{abstract}

Key words: ISO 9001; quality management; standards; occupational health and safety; wages; labor; empirical; California

\section{Introduction}

Nearly 900,000 organizations in 170 countries have adopted the ISO 9001 Quality Management System standard. ${ }^{1}$ This is a remarkable figure given the lack of rigorous evidence regarding the standard's effect on organizational practices and performance. Implementing a quality management system that

\footnotetext{
${ }^{*}$ Corresponding author. DeYett Law and Xiang Ao provided outstanding research assistance. We appreciate the support of Christine Baker and Irina Nemirovsky of California's Commission on Health and Safety and Workers' Compensation, Dave Bellusci and Tim Basuino of the Workers' Compensation Insurance Rating Board, and helpful comments from Frank Neuhauser. We are grateful for financial support from the Commission on Health and Safety and Workers' Compensation, Harvard Business School's Division of Research and Faculty Development, Kauffman Foundation, University of California at Berkeley's Institute for Research on Labor and Employment, and University of California's Labor and Employment Relations Fund. We thank Vishal Gaur, Andrew King, Dan Levine, and Amy Nguyen-Chyung for their insightful comments.

1 International Organization for Standardization, The ISO Survey of Certifications: 2006, available at http://www.iso.org/iso/iso_catalogue/management_standards/certification/the_iso_survey.htm (accessed May 21, 2008).
} 
conforms to ISO 9001 entails documenting operating procedures, training, internal auditing, and corrective action procedures. It also requires that procedures to improve existing procedures be implemented.

Proponents claim that quality programs such as ISO 9001 improve both management practices and production processes, and that these improvements translate into increased sales and employment (unless productivity gains outweigh sales increases). The latter benefits are magnified if customers interpret the adoption of ISO 9001 or other quality programs as a signal of high quality products or services. To the extent that greater employee skill and training are required to develop and implement procedures to improve procedures, the theory of human capital suggests that employees' earnings should rise as well. Finally, ISO 9001 can improve worker safety through the identification and elimination of potentially hazardous practices, development of a formal corrective action process, and institutionalization of routine audits and management reviews. Some critics suggest that such formalization and documentation of work practices can negatively affect employees, such as by reducing skill requirements or increasing cumulative trauma disorders (e.g., Brenner, Fairris, and Ruser 2004).

This paper reports the first large-scale empirical evaluation of how workers' outcomes change with employers' adoption of ISO 9001, focusing in particular on employment, total payroll, average annual earnings, and workplace health and safety. We also examine outcomes of importance to company managers and owners such as whether ISO 9001 is associated with subsequent sales growth and longerterm company survival. Focusing on California-based single-plant firms across an array of industries, we compared ISO 9001 adopters to comparison groups of non-adopters matched on industry, location, size (baseline sales, employment, and total payroll), and pre-adoption injury rates. A difference-in-differences approach was employed to accommodate common shocks that affect each industry. Company characteristics that vary over time, such as size and changes in occupational mix, were controlled for when appropriate.

We find ISO adopters have higher rates of corporate survival, sales and employment growth, and wage increases than the matched groups of non-adopters. We further find adopters to be more likely than 
non-adopters to report no injuries (as measured by workers' compensation claims) in the years following adoption, but find no evidence that average injury costs improve or worsen subsequent to adoption.

\section{Literature}

In this section, we review the literature that has examined changes in outcomes consequent to the adoption of ISO 9001. We consider first studied focusing on outcomes of particular interest to owners and managers, such as profitability. We then review the considerably smaller literature that examines outcomes of particular interest to employees, such as employment and injury rates.

\subsection{Organizational outcomes}

Among the most rigorous empirical studies that examine how implementation of the ISO 9001 quality management standard affects employers' outcomes and practices, most were conducted among U.S. manufacturers. ${ }^{2}$ Terlaak and King (2006) find that plants that adopt ISO 9001 typically increase their rate of production growth. Others find ISO 9001 certification to be associated with subsequent abnormal returns along a host of financial metrics including stock prices (Corbett, Luca, and Pan 2003; Sharma 2005). Various studies find benefits strongest among small firms (Docking and Dowen 1999; McGuire and Dilts 2008) and among those with a modest level of technological diversity, and/or early adopters (Benner and Veloso 2008). King and Lenox's (2001) finding that adopting ISO 9001 leads plants to reduce waste generation and toxic chemical emissions suggests that implementing the quality management standard has positive spillover effects that can improve environmental management practices. Naveh and Erez (2006) deduce from survey data that ISO 9001 adoption enhances worker productivity and workers' attention to detail, but impedes worker innovation. Interestingly, we found no prior research that examines how the ISO 9001 quality standard affects product or process quality or employees. Similarly, albeit outside the realm of ISO 9001, a number of event studies find that financial performance, as measured by stock price and operating income, improves after firms win a quality award

${ }^{2}$ A much larger literature examines why firms adopt the ISO 9000 standard. See Corbett, Montes-Sancho, and Kirsch (2005) for a comprehensive review. 
or implement Total Quality Management programs (Easton and Jarrell 1998; Hendricks and Singhal 1996, 1997, 2001a, 2001b). ${ }^{3}$

Several studies have found ISO 9001 adopters' financial performance to be superior to that of peers prior to, but not after, registration (see Heras, Gavin, and Dick 2002 for evidence from Spain; Häversjö 2000 for evidence from Denmark; and Simmons and White 1999 for evidence from the United States). These studies are consistent with a positive selection effect, but do not suggest any causal benefits associated with ISO registration. We return to the distinction between correlation and causality in the subsequent analyses.

\subsection{Employee outcomes}

We found almost no prior research that examines how the ISO 9001 quality management standard affects key outcomes of interest to employees, such as employment and earnings. ${ }^{4}$ Among the few studies that have examined how other quality programs affect occupational health and safety is Adler, Goldoftas, and Levine's (1997) case study of a General Motors automobile plant. They found that the plant's suspension of job rotation subsequent to the adoption and implementation of the Toyota Production System's quality principles precipitated a dramatic rise in cumulative trauma disorders (CTDs), leading the authors to conclude that Toyota Production System principles such as short cycle times, standardized work methods, and minimizing worker idle time increase the risk of CTDs. These findings are consistent with those of Wokutch's (1992) study of Japanese auto transplants in the United States. In contrast, Adler et al. (1997) found other Toyota Production System principles, such as employee focus on continuous improvement, to help reduce injury rates, provided employees were empowered to focus on safety and health issues.

A few larger-scale studies have examined the relationship between quality management practices and

\footnotetext{
${ }^{3}$ See Wayhan and Balderson (2007) for a comprehensive review of studies that examine how implementing Total Quality Management affects financial performance.

${ }^{4}$ In a suggestive small study (45 ISO adopters), O'Connor (2005) found that Oregon employers with ISO certification increased employment more rapidly than peers in their industry. The analysis neither controlled for employer size nor tested for statistical significance.
} 
worker injuries. Lean production practices such as faster work pace and reduced cycle time have been found to be positively associated with worker stress (Conti et al. 2006) and quality circles and job rotation with CTDs (Brenner et al. 2004). But their reliance on data collected simultaneously for workplace practices and illness/injury rates precludes these studies from distinguishing selection from causal effects. $^{5}$

Naveh and Marcus's (2007) analysis of the road safety experience in the trucking industry found that, compared to peer firms, 40 adopters of ISO 9002 reduced more quickly their accident rates after certification. Presumably due to the modest sample size, the results are not consistently statistically significant.

This paper reports the results of the first large-scale study to examine changes in employee outcomes after their employer adopts ISO 9001, including wages and frequency and magnitude of worker injuries. We also examine changes in organizational outcomes such as sales, employment, and company survival. Analyzing a plant-level panel dataset that includes an array of worker outcomes avoids the small sample sizes and/or lack of longitudinal data that have plagued previous studies. Because ISO 9001 is typically adopted at the plant-level whereas outcome data is typically available only at the firm level, we focus on single-plant firms. Our data and methods enable us to clearly distinguish the effects of selection on observables from post-adoption divergences in trends. Moreover, whereas prior studies of safety and health have relied largely on self-reported survey data, we measure injury rate and cost of injuries using workers' compensation data. This approach reduces both random measurement error and potential bias arising from ex post rationalization by managers who both initiate a quality program and report its outcomes.

\footnotetext{
${ }^{5}$ For example, Brenner, Fairris, and Ruser (2004) interpret the positive association of unions with cumulative trauma disorders as selection effects of unionization, the positive association of job rotation with cumulative trauma disorders as reverse causality (whereby high rates of repetitive motion injuries lead plants to introduce job rotation), and the positive association of quality circles and just-in-time production with cumulative trauma disorders as causal effects of the work practices. Fairris and Brenner (2001), using panel data to address causality, found CTD rates in their industry to decline after plants adopted self-directed work teams or Total Quality Management, but average industry CTD rates to increase after plants implemented quality circles or job rotation. But because these workplace practices could be linked only to industry-level (3-digit SIC codes) CTD rates, it is difficult to interpret these results.
} 


\section{Theory and Hypotheses}

Companies that implement a quality management system that conforms to ISO 9001 typically improve the documentation of operating procedures, training, and procedures for corrective action. A plant seeking ISO 9001 certification must hire an accredited third-party auditor to attest that (1) written procedures exist for all significant operations, (2) training, monitoring, and other procedures are in place to ensure that written procedures are followed, and (3) procedures for continuously improving other procedures have been implemented. The latter requirement has implications for employees' training, incentives, and scope of decision-making. The cost of implementing ISO 9001, including developing procedures, documentation, and training and hiring a third-party auditor, range from $\$ 97,000$ to $\$ 560,000$ (in 2008 dollars), depending on the size and complexity of the operation (Docking and Dowen 1999). ${ }^{6}$

\subsection{ISO 9001 and changes in plant scale}

For products and services for which it is difficult to distinguish higher from lower quality, there is little incentive either for customers to pay a premium for, or for companies to invest in, higher quality (Spence 1973). Firms can benefit from ISO 9001 certification in such circumstances. In particular, if ISO 9001 certification is more often profitable for higher quality firms, ISO 9001 can signal to buyers that adopters likely possess high quality (Spence 1973; Terlaak and King 2006). If certification serves to credibly differentiate higher quality products and services, certified firms should see an increase in demand, which would also result in increased unit sales and total revenues. ISO 9001 certification can also increase customers' willingness to pay for quality, which creates an incentive for managers to invest in improving product or service quality. If certification teaches managers to cost-effectively improve quality along dimensions customer perceive and value, such firms should also see an increase in unit sales and total revenues.

ISO 9001 adoption can also help managers learn how to reduce costs. Under standard economic assumptions, a profit-maximizing firm sets price as a mark-up over marginal cost. To the extent that

\footnotetext{
${ }^{6}$ We adjust the cost range in Docking and Dowen (1999) using the BLS Inflation Calculator (U.S. Department of Labor, Bureau of Labor Statistics, http://www.bls.gov/; accessed June 7, 2008).
} 
adoption helps them to learn how to lower their marginal costs, certified firms should reduce their prices.

Holding all else constant, these lower prices should translate into increased unit sales and revenue.

Whether high-quality firms are more likely to adopt ISO 9001, or the standard improves adopters' quality or costs, both scenarios give rise to the same prediction: ISO 9001 certification will increase sales. Indeed, many industrial buyers use ISO 9001 certification in their screening criteria for potential suppliers, believing that it "almost guarantees that [their] products will consistently meet their design specifications" (Ferguson 1996: 309). These scenarios indicate that such revenue increases will be accompanied by constant or declining operating costs (thereby increasing profits), which implies that ISO 9001 certification should be associated with greater probability of firm survival.

HYPOTHESIS 1a: ISO 9001 certification leads to higher rates of firm survival. HYPOTHESIS 1b: ISO 9001 certification leads to higher sales. ${ }^{7}$

If the hypothesized increase in revenues is due to increased unit sales (not solely increased prices) and the demand for additional units cannot be accommodated by existing worker capacity, we also have:

HYPOTHESIS 2a: ISO 9001 certification leads to higher employment, but by less than sales increases.

If, as suggested by survey data, ISO 9001 can also enhance worker productivity (Naveh and Erez 2006), employment growth will be proportionately less than sales growth, leading to: ${ }^{8}$

HYPOTHESIS 2b: ISO 9001 certification leads to higher labor productivity.

\subsection{ISO 9001 and wages}

The effect of ISO 9001 adoption on wages can be positive or negative. ${ }^{9}$ Helper, Levine, and Bendoly (2002) found that attempts to foster employee involvement led to higher wages meant to compensate the

\footnotetext{
${ }^{7}$ Hypothesis $1 \mathrm{~b}$ might not hold if a firm increased its quality (or quality certification) to target a market segment that focused on high quality and that had very price-inelastic demand. In such a case, mark-up, prices, and profit per unit all rise. If the high-quality niche is both very profitable per unit and small, then unit sales might decline even as profits rise. If unit sales fall enough (by a higher proportion than the mark-up rises), sales revenue can decline, even though the higher total profits increases firm survival. (We thank an anonymous referee for pointing out this possibility.)

${ }^{8}$ If the productivity gain is greater than the increase in unit sales, employment can decline, a case we do not consider further.

${ }^{9}$ These hypotheses are elaborated in Helper et al. (2002).
} 
incremental effort expended to achieve the requisite higher skill levels. Employees of ISO 9001 adopters are often expected to perform discretionary tasks such as documenting new procedures and contributing quality improvement ideas. ISO 9001 adopting plants must develop and deploy quality-related training to ensure that employees properly implement new procedures and acquire the skills needed to conduct internal audits and root-cause analyses and continuously improve other procedures. Reliance on greater employee discretionary efforts and enhanced skills (as in theories of human capital) can lead firms to pay higher wages (to induce greater effort, as in efficiency wage theories [Levine 1992]) or increase employees' bargaining power (Lindbeck and Snower 1986). If greater human capital, efficiency wages, and/or bargaining power are important, we have:

HYPOTHESIS 3: ISO 9001 certification leads to higher wages.

Rigorous adherence to written procedures, on the other hand, implies a fairly routinized workplace, and routinization is often associated with reductions in frontline workers' skills, discretion, and bargaining power. (A plant encountered in the course of our field research, for example, was implementing ISO 9001 with the express purpose of documenting workers' tacit knowledge and procedures so that the plant could be replicated overseas using lower cost labor.) When this condition prevails, we have:

HYPOTHESIS 3': ISO 9001 certification leads to lower wages.

\subsection{ISO 9001 and occupational health and safety}

Adopting ISO 9001 might lead to improvements in occupational health and safety in a variety of ways. In the process of formally documenting procedures, for example, managers can identify and eliminate hazardous practices and add safety precautions. Moreover, by fostering more focused attention to detail (Naveh and Erez 2006), ISO 9001 adoption can reveal new "win-win" opportunities to improve quality or efficiency and occupational health and safety that were previously obscured by indirect and distributed costs and benefits (King and Lenox 2001). Additionally, processes that provide warning signals and prompt corrective action can forestall serious accidents (Marcus and Nichols 1999). Finally, routine auditing and corrective action procedures required by ISO 9001 to address management system 
failures encourage root-cause analysis that can identify problematic work practices that might otherwise precipitate not only quality failures, but occupational health and safety concerns.

Departments charged with managing quality sometimes also manage health and safety, and companies are increasingly implementing integrated management systems that incorporate all these considerations (Toffel 2000; Barbeau et al. 2004). Occupational health and safety can be improved by applying the tools of continuous improvement associated with ISO 9001 certification. Employees who know how to identify root causes of quality problems, for example, also have the skills to identify root causes of safety problems. Exploiting these opportunities yields:

HYPOTHESIS 4: Adopting ISO 9001 reduces the number and cost of occupational injuries.

The high rates of repetition and increased monitoring implicit in the emphasis of ISO 9001 on routinization and standardization of tasks can increase stress and repetitive motion injuries, potentially worsening the safety records of plants with quality programs (as argued by Brenner et al. 2004). Moreover, to the extent that the higher equipment utilization associated with ISO 9001 adoption (Koc 2007; Huarng, Horng, and Chen 1999) translates into reduced employee downtime, employee fatigue, a major cause of injuries, might be expected to increase (Williamson and Boufous 2007). Additionally, new quality management procedures implemented in association with ISO 9001 that add inspection tasks to work processes optimized for production can occasion poor ergonomic conditions that leave employees susceptible to injuries (Landau and Peters 2006). These considerations give rise to:

HYPOTHESIS 4': Adopting ISO 9001 increases the number and cost of occupational injuries.

\section{Data}

\subsection{Sample}

Because the typical scope of ISO 9001 certification is a single plant, but injury data from workers' compensation systems are available primarily at the company level, we facilitate the linking of ISO certification data to injury data by restricting our sample to single-plant firms. According to 2005 Dun \& Bradstreet data, approximately $80 \%$ of manufacturing plants in California are single-plant firms.

According to the ISO 9000 Registered Company Directory produced by QSU Publishing Company, 
5,995 companies in California were ISO 9001 certified at the end of 2005. Linking this list of company names and addresses with Dun \& Bradstreet data yielded 1,846 ISO 9001 certified single-plant firms.

The Workers' Compensation Insurance Rating Board (WCIRB), a nonprofit association of all firms licensed to provide workers' compensation insurance in California, provided annual workers' compensation and payroll data for 1993 through 2003 (the latest year available at the time due to reporting lags) from its Uniform Statistical Reporting Plan database. WCIRB linked to its database $77 \%$ $(1,418)$ of our single-plant ISO 9001 adopters, similar to the proportion of California firms from which WCIRB gathers workers' compensation data (i.e., firms that obtain workers' compensation insurance rather than self-insure).

Linking the WCIRB provided names and addresses of the 116,389 non-adopting firms that shared the same region-industry combinations as the adopters to Dun \& Bradstreet data confirmed that 20,777 of these non-adopters were single-plant firms.

We obtained from the National Establishment Time-Series (NETS) database, a compendium of Dun \& Bradstreet data, annual employment and sales data for most of the ISO adopters and potential matches, 1,079 adopters and 18,480 non-adopters, for 1993-2005. Eliminating firms with missing values and outliers (as detailed in the following section) reduced the final sample used for our selection analysis to 916 adopters and 17,849 non-adopters. Sample characteristics are provided in Table 1. As described below, we identified subsets of these firms to create matched samples for analyzing the effects of ISO certification.

\subsection{Measures}

Injury rate is the number of injuries reported annually for which workers' compensation was claimed according to WCIRB data. Our models employ the log of one plus the injury rate. We also obtained from WCIRB data each company's total annual workers' compensation injury costs and annual total payroll ${ }^{10}$ (both in dollars). To reduce the effect of outliers, we took the log of injury costs after adding $\$ 1,000$. Also

\footnotetext{
${ }^{10}$ Our payroll measure is what WCIRB calls "exposure," which equals total payroll after subtracting overtime pay, shift premiums, and a few other minor adjustments for each of 500 occupational class codes.
} 
obtained from WCIRB data were each company's location in one of 15 industries and eight California regions (see Table 1).

For each firm-year, we calculated average occupation riskiness as a weighted average of workers' compensation Pure Premium Rates across a firm's employment in 500 occupation codes. ${ }^{11}$ The intuition behind this measure is that for an employer that has, in a given year, a workforce in occupations for which workers' compensation costs are, on average, twice state-wide workers' compensation costs, average occupational riskiness for the firm-year would be twice the state average. For each year, we calculated each firm's average wage as its annual total payroll (from WCIRB) divided by its employment (from Dun \& Bradstreet).

We then cleaned the dataset as follows. Sales of zero were recoded to missing and firm-years with less than $\$ 5,000$ in payroll were omitted. To avoid our analysis being confounded by rapidly growing or shrinking firms, we included only observations for which a firm's payroll (and employment) in a given year was between half and twice the previous year (when the previous year's data were available). We also sought to exclude firms that operated only part of the year by omitting firm-years for which the average wage was below $\$ 7,020$ (what a half-time worker would earn at California's 2002 minimum wage). To reduce the effect of outliers, we analyzed the log of payroll, average occupational riskiness, employment, average wage, and sales after adding a small amount to accommodate zeros and other small values.

Summary statistics are provided in Table 2 .

11 Pure Premium Rates are established by WCIRB based on historical workers' compensation costs for each occupation.

We calculated a firm $f$ 's average occupational hazardousness in a given year $t$ as:

average occupational hazardousness $\mathrm{ft}_{\mathrm{ft}}=\frac{\sum_{c} \text { payroll }_{c f t} \times \text { Pure } \text { PremiumRate }_{c}}{\text { payroll }_{\mathrm{ft}}}$

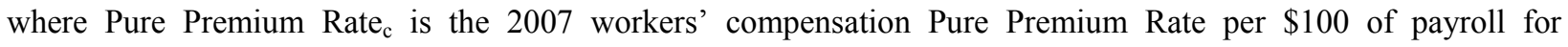
occupation class code $c$ and payroll is the measure of total payroll defined as in the previous footnote. 


\section{Analysis and Results}

\subsection{Selection model}

The main goal of this paper is to identify causal effects of ISO 9001 adoption for employees and employers. ISO 9001 adoption could correlate with, but not cause, outcomes if a factor such as good management led to both ISO adoption and positive outcomes. If this form of self-selection is important, we anticipate ISO adopters to have had good outcomes prior to ISO adoption as well as afterwards. To understand the self-selection process, we estimate the selection model:

1) $I S O_{i t}=F\left(Y_{i t-1 \&-2}\right.$, year $_{t}$, industry $_{i}$, region $\left._{j}, u_{i t}\right)$

where $\mathrm{F}($.$) is the probit function, Y_{i t-1 \&-2}$ is the average of 1- and 2-year lagged levels of injury rates and costs, payroll, employment, wages, sales, and average occupational riskiness, ${ }^{12}$ year $_{t}$ is a complete set of

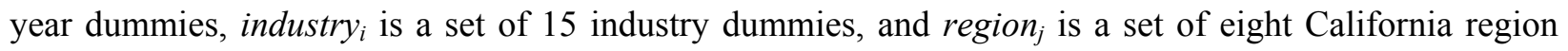
dummies. Because we are interested in the determinants of adoption, we drop adopters from the sample after the year of adoption. To account for heteroscedasticity and non-independence among each firm's observations across years, we report robust standard errors clustered by firm.

\subsection{Results of selection analysis}

The main result on selection is that ISO 9001 is adopted more often by larger firms. Median sales and payroll of adopting firms are \$3.48 million and \$1.04 million, whereas these figures are \$0.78 million and \$0.16 million, respectively, for non-adopters. We examine this issue more carefully with the adoption probit regression, which reveals larger firms (in terms of sales and total payroll) adopted ISO 9001 at a higher rate than other firms in their industry, year, and region (see Table 3). If, for example, one employer has one log point (roughly one standard deviation) higher sales and payroll than average, the sum of the marginal effects predicts a 0.06 percentage point above-average probability of ISO 9001 adoption per year, most of the effect attributable to higher payroll. This increase equals roughly $11 \%$ of the sample mean, which is 5.4 out of a thousand firms adopting each year. Because adoption entails fixed costs-

\footnotetext{
${ }^{12}$ When only one of the two lagged values was available, we used that single value.
} 
including learning about the standard's requirements and developing policies, procedures, and training programs - it is not surprising that larger firms are more likely to make the investment in ISO 9001 certification.

The sales coefficient is statistically significant and economically meaningful after controlling for both payroll and employment. Thus, ISO adopters had above-average labor productivity prior to adopting ISO 9001. Note that the marginal effect of payroll $(0.00046, p<0.01)$ is higher than the marginal effect of employment (0.00009, n.s.), which suggests that ISO 9001 adopters paid above-average annual wages prior to ISO adoption (or that WCIRB data on payroll is more precisely measured than D\&B data on employment). If higher wages correlate with higher skills, and higher skills with higher quality, this result suggests that ISO adopters might already have been delivering above-average quality prior to ISO adoption (relativee to their industry and region).

ISO 9001 adopters also had slightly lower workers' compensation injury costs, so that one log point lower injury costs (a bit less than one standard deviation) predicts $0.005 \%$ higher adoption of ISO 9001 in the next year $(\mathrm{p}<0.05)$. Our statistically insignificant coefficient on injury rates and its tiny marginal effect provide no evidence that annual number of injuries prior to adoption differed between adopters and non-adopters.

\subsection{Differences in trends following ISO 9001 certification}

We conduct a difference-in-differences analysis to compare the changes in payroll, employment, wages, sales, average occupational riskiness, and injury rates and costs among ISO-certified firms to those of non-adopters. This approach permits each firm to have its own baseline level of each outcome. To ensure a valid comparison, we developed a matched control group of non-adopters.

\subsubsection{Developing matched samples}

Matching is widely used to construct a quasi-control group based on similar characteristics to those of the treatment group (Heckman, Ichimura, and Todd 1998). Intuitively, we want to compare companies that adopt ISO 9001 to industry peers with similar pre-adoption sales, employment, payroll, injury rates, and other observable factors. 
Matching on the propensity score, the probability of receiving the treatment conditional on covariates, is as valid as matching on a series of individual covariates (Rosenbaum and Rubin 1983). The identifying assumption, that the assignment to the treatment group is associated only with observable "pre-period" variables and all remaining variation across the groups is random, is often referred to as the "ignorable treatment assignment" or "selection on observables."

Used to evaluate job training programs, propensity score matching methods have performed well in replicating the results of randomized experiments under three conditions: (1) the same data sources are used for participants and non-participants; (2) an extensive set of covariates is employed in the programparticipation model used to estimate propensity scores; and (3) participants are matched with nonparticipants in the same local labor market (Smith and Todd 2005). Conversely, substantial bias can result if: (4) controls are included for which propensity scores are off the support of the participants' propensity scores (that is, some of the controls differ substantially from any of the treatments); (5) the distributions of participants' and non-participants' propensity scores differ; or (6) unobservable factors influence both participation and outcomes (Heckman, Ichimura, and Todd 1997).

We address these six potential sources of bias as follows. First, we use identical data sources for all facilities (adopters and non-adopters). Second, we include an extensive set of adoption covariates. Third, we ensure that adopters and non-adopters operate within the same markets by including industry and region as matching criteria. We address the fourth and fifth concerns by implementing nearest neighbor matching with a "caliper" restriction to preclude matching when the propensity scores differ by more than a fixed threshold (as explained below).

The sixth concern addresses selection on unobservables. For example, in the context of ISO 9001, it is possible that managers in facilities with a "safety culture" (not observed in our data) might be more likely both to insist on strong safety performance and to adopt ISO 9001. We address this concern in two ways. First, we control for such unobserved factors that are stable over time by including a fixed effect for each employer. Second, if there were important unobservable factors that affected company success and that differed between ISO adopters and our comparison firms, we would expect the pre-adoption trends in 
sales, employment, earnings, and injury rates and costs to differ between treatments and comparisons. In fact, after we matched on the level of sales, employment, and so forth, we found our comparison firms had similar pre-adoption trends as our treatments. This result is not conclusive, but provides some assurance that we are doing a good job controlling for unobservable factors as well.

Propensity score matching to develop a matched control group on which to estimate treatment effects with a difference-in-differences specification (as explained below) using panel data is a robust technique used in other recent program evaluations (e.g., Blundell et al. 2004; Galiani, Gertler, and Schargrodsky 2005; Greenaway, Gullstrand, and Kneller 2005; Huttunen 2007; Qian 2007; Villalonga 2004). We implemented propensity score matching in three steps. We first generated propensity scores by estimating a probit model for adoption status during 1994-2003 that included a full set of year dummies, 15 industry dummies, and eight California geographic region dummies. We also included lagged levels of each of our outcome variables: injury rates and costs, payroll, employment, wages, sales, and average occupational riskiness. We employed a highly flexible functional form by including the average level of the prior two years as well as the log and square of this average. Table A1 in the On-line Appendix contains descriptions of, and summary statistics for, the variables used in the matching process. Because we are interested in the determinants of adoption, we drop adopters from the sample after the year of adoption. The results of this probit are reported in Table A2 in the On-line Appendix. The predicted probability of adoption estimated from this probit model is our estimated propensity score.

We then implemented single nearest neighbor matching. Specifically, we matched each adopter during its certification year to the non-adopter in the same industry with the most similar propensity score for that year and that had data for at least one subsequent year. ${ }^{13}$ The latter requirement resulted in our

\footnotetext{
${ }^{13}$ In our context, a firm's decision to adopt ISO 9001 in a particular year is contingent on its not having previously adopted. Because firms face a greater likelihood of adopting as time passes, the adoption decision is more akin to a geometric random variable than a Bernoulli random variable considered in some other contexts that use propensity score matching. Our matching protocol includes several steps to ensure that each adopter and its matched control face a similar risk of adoption. First, we compare the adopter's propensity score to non-adopters' propensity scores generated in the same year to ensure that all firms face the identical time lag since the ISO 9001 standard emerged. Second, we implement nearest neighbor matching using contemporaneous propensity scores by selecting the non-
} 
matching firms that adopted only through 2002, because the WCIRB data extended only through 2003. We refer to the absolute difference between the two propensity scores in a matched pair of firms as the "match distance." Of the 892 adopters for which we estimated propensity scores, we successfully matched 550 adopters to 550 controls. $^{14}$

Next, we assessed the quality of these matches and refined our matched sample. To confirm whether our matching process resulted in a highly comparable set of adopters and non-adopters, we compared the two groups' lagged levels of seven outcome variables: number of injuries, injury costs, payroll, employment, wages, sales, and average occupational riskiness. The identifying assumption of the difference-in-differences approach is that the treatment group's trend during the post-period would have been indistinguishable from the control group's trend had the treatment not occurred. To examine the plausibility of this assumption, we compared the two groups' performance trends in the period prior to ISO adoption (as in Barber and Lyon 1996; Dehejia and Wahba 1999; Eichler and Lechner 2002) using two measures of pre-adoption trends: (1) the percent change in lagged performance comparing a threeand-four-year lagged average to a one-and-two-year-lagged average; and (2) the difference in the log of these two averages (after adding a small constant before taking the log). T-test results indicated statistically significant differences at the $10 \%$ level for nine of the 21 comparisons made for levels or trends, far more than would be expected by chance.

This first stage of matching not yielding a very credible comparison group, we attempted to improve match quality by dropping pairs for which the propensity scores of the ISO adopters and potential matches exceeded a given caliper size. A smaller caliper means ISO adopters are more similar to their matches, but reduces the sample size. We tried various values, settling on a caliper of 0.07 , which yielded

adopter in the same industry with the propensity score most similar to that of the adopter in the year of adoption.

${ }^{14}$ A potential concern is that the 550 adopters in the matched sample might differ from the 342 adopters for which we were unable to identify matched controls. We used t-tests to compare the log of the two-year lagged average levels of each of our outcome variables. The results provided little evidence that these groups of adopters differed during the pre-adoption period, as the two groups had statistically indistinguishable injury costs, payroll, employment, wages, and occupational riskiness. For the two outcomes in which the groups statistically differed during the pre-adoption period, the matched adopters had somewhat higher injury rates and lower sales. Kernel density graphs revealed the two groups of adopters to have very similar distributions for each of the seven lagged outcomes. Together, these results provide little evidence that matched adopters differed from unmatched adopters. 
a closely matched albeit slightly smaller set of 471 pairs of adopters and controls. In this caliper-restricted matched sample, t-tests revealed the groups to differ along only one of the 21 metrics at the $5 \%$ level and four of the 21 metrics at the 10\% level (see Table A3 in the On-line Appendix). We ran our evaluation model on this matched sample (Table 4 provides summary statistics).

Development of the matched sample for the survival analysis followed a slightly modified version of this matching process. Specifically, we (1) no longer excluded firms that lacked data after the match year, and (2) matched firms that had adopted as late as 2003. Generating propensity scores and matching firms under these modifications yielded 622 pairs of adopters and non-adopters.

\subsubsection{Organizational survival}

We use both nonparametric methods and duration models to examine the survival rates of our matched pairs of adopter and non-adopter firms. Because our dataset extends through 2003 and matching each ISO adopter to its control firm was done in a specific year, data on both firms in the pair were right censored after the same number of years at risk of firm death. A firm was considered to have died when it disappeared from both the D\&B and WCIRB datasets. ${ }^{15}$

Of the 622 pairs of firms that constitute our matched sample for the survival analysis, $0.5 \%$ of adopters and $7.1 \%$ of controls had disappeared from both the Worker's Compensation (WCIRB) and Dun \& Bradstreet (D\&B) datasets by 2003. A t-test confirmed adopters' survival rates to be statistically significantly higher $(\mathrm{p}<0.01)$.

Although the analyses of raw survival rates use a matched sample, there remain within each pair small differences in observable factors. In Table A4 in the On-line Appendix, we present the results of a cross-sectional logit model, a conditional logit model (with a conditional fixed effect for each pair), and a

\footnotetext{
15 One concern might be that firms that disappeared from these databases through mergers or acquisitions nonetheless continued to operate. To check D\&B's success rate in tracking organizations after mergers and acquisitions, we searched for news articles on the 47 firms that "died" in our survival analysis. We found news reports that 16 of these firms had merged or been acquired. In 15 of these 16 cases, our D\&B data (from the NETS database) shows either (a) no other establishments at the same location after the year we recorded firm death, or (b) only unrelated companies (not the acquirer) at the same location. It thus appears that almost all of these "merged" or "acquired" establishments closed or relocated subsequent to acquisition, reassuring us that our coding of firm death captures the intended construct.
} 
stratified Cox proportional hazard model (with each pair its own strata, similar to a fixed effect in survival probabilities for each pair). These models enabled us to condition on numerous observable factors such as pre-adoption sales and employment. The Cox model also accommodates our data being right-censored, in that some firms continued to survive at the end of our sample period. As expected, the large survival advantage of ISO adopters persists in these specifications, providing robust support for Hypothesis 1a, that ISO adoption increases a company's survival rate.

\subsubsection{Evaluation model}

We assess differences in post-ISO 9001 adoption trends via a difference-in-differences analysis. Specifically, we estimate the following model for each outcome $Y_{i t}$ at firm $i$ in year $t$ :

(2) $\quad Y_{i t}=\alpha_{i}+\beta \cdot I S O_{i t}+\gamma \cdot X_{i t}+\delta_{t} \cdot$ year $_{t}+\varepsilon_{i t}$

where $\alpha_{i}$ is a complete set of firm-specific intercepts. Only the ISO 9001 adopting firm in each pair of matched firms ever has a positive value of the dichotomous variable $I S O_{i t}$, which for such firms is coded "1" for all years after the firm is ISO 9001 and " 0 " before then. Of primary interest is its coefficient, $\beta$, the estimated effect of achieving certification. We also include a full set of year dummies (year $)_{t}$. Depending on the outcome variable being estimated, we include in $X_{i t}$ controls for the firm's current log of payroll, employment, sales, average occupational riskiness, or number of injuries (see Tables 5 and 6).

We also employ a variation of this specification that refines our ability to measure the effects of certification. In Equation 2, the single post-certification dummy $I S O_{i t}$ estimates an overall average change in outcome levels, pre- to post-adoption. But such improvements might be large in the first few years after adoption and then attenuate, or take several years to emerge. To estimate potential effects each period after certification, we include dummies coded "1" for adopters "one to three years after certification," "four to six years after certification," and "seven to nine years after certification."

Employer outcomes. Results of the difference-in-differences evaluation model of employment and sales are presented in Table 5. All of these models employ the matched sample, using years in which both the ISO 9001 adopter and matched control survived. Employment is about 10 percentage points higher in ISO-certified workplaces after certification (column $1, \mathrm{~b}=10.3 \%, \mathrm{p}<0.01$ ) than in comparison firms, 
strongly supporting Hypothesis 2a, which predicts higher employment growth at ISO 9001 firms. Column 2 reveals that this increase grows over time, from $6.1 \%(\mathrm{SE}=1.8 \%, \mathrm{p}<0.01)$ in years $1-3$, to $22.5 \%$ in years 4-6 $(\mathrm{SE}=2.9 \%)$, to a quite large $32.5 \%$ in years $7-9(\mathrm{SE}=6.3 \%)$. Because only 62 of our 471 matched ISO 9001 adopters (13\%) adopted seven or more years prior to the end of the matched dataset used for these models, results in this category are typically not precisely estimated. Nevertheless, the high employment growth in years 7-9 is statistically significant from the average effect $(\mathrm{p}<0.01)$ and from the effect in years 1-3 (Wald test $\mathrm{F}=17.70, \mathrm{p}<0.01$ ), though not from the effect in years 4-6.

Sales are almost nine percentage points higher at ISO 9001 firms than at comparison firms (column 3), which supports Hypothesis 1 b. Column 4 reveals that this advantage does not show up until year 4 and beyond (effect size in years $4-6=25 \%, \mathrm{SE}=4.0 \%$; which is statistically indistinguishable from the effect size in years $7-9$ of $17 \%, \mathrm{SE}=8.8 \%, \mathrm{p}<0.10)$.

This increase in sales is roughly what would be expected from the higher payroll at ISO-certified firms (column 5). There is suggestive evidence of growth in sales conditional on payroll in years 4-6 after certification (column $6, \mathrm{~b}=+13.2 \%, \mathrm{p}<0.01$ ). In contrast, the coefficient is small, less than $2 \%$ in absolute value, and not statistically significant in years 1-3 and 7-9. Hypothesis $2 b$, which predicts gains in labor productivity, is thus not supported. In results not shown, sales also did not increase statistically significantly faster at ISO adopters if we controlled for employment instead of payroll; that is, total sales rose at adopters relative to matched non-adopters, but not sales per employee.

Employee outcomes. The results of our evaluation model for employee outcomes are presented in Table 6. Column 1 reveals that total payroll at ISO firms grew about $17.7 \%$ more than at matched control firms $(\mathrm{SE}=1.7 \%, \mathrm{p}<0.01)$, increasing steadily over time from $14 \%$ in years $1-3$ to $36 \%$ in years $7-9$ (column 2). Nearly a third of this increase in payroll (measured using workers' compensation records) appears to be due to higher employment (measured using D\&B data). That is, conditioning on employment, payroll at ISO-certified firms grew about $13.5 \%$ more than at comparison firms $(\mathrm{SE}=1.6 \%$, $\mathrm{p}<0.01$, column 3 ), increasing steadily over time from $11.7 \%$ in years $1-3$ to $22 \%$ in years $7-9$. It is plausible that the correlation of total payroll and employment would be higher were they measured from a 
common data source. ${ }^{16}$

Recall that we measured wages as total payroll from workers' compensation records divided by employment data from D\&B. Keeping in mind all the caveats that attend such a measure, the results indicate that annual wages grew to be about $7.5 \%$ higher at ISO firms than at their matches (column 5), supporting Hypothesis 3, that ISO 9001 adoption leads to higher wages (and not Hypothesis 3', that adoption lowers wages). Although the point estimates decline over time, we cannot reject the null that the coefficients are constant over time (column 6).

Unlike the previous outcomes, our estimates of the effect of ISO 9001 adoption on injury rates and costs are conditioned on employment, payroll, sales, and average occupational riskiness. We find trends in the total value of injury costs (columns 7 and 8) and average cost per injury (columns 9 and 10) to be unrelated to ISO 9001 certification (among pairs of firms both of which had at least one injury).

Number of injuries, a count variable, is analyzed via a negative binomial regression model with firmlevel conditional fixed effects. Because the conditional negative binomial model compares a firm's injury rate in a given year with its average injury rate, it does not provide estimates for firms that lack annual variation in injury rate. The model drops such firms from the sample. (This is the same restriction as a conditional logit, for example.) To maintain a matched comparison, we thus included in this sample only pairs in which both adopter and matched non-adopter reported at least one injury. The results indicate that adoption did not predict a higher or lower number of injuries among employers that had at least one injury during our sample period (Table 6, columns 11 and 12, conditioning on employment and other control variables).

The workers' compensation data show a small shift to safer occupations at firms that become ISO 9001 certified. That is, the average worker in a post-certification firm works in an occupation for which workers' compensation costs are almost $5 \%$ lower than at the comparison firm $(b=-0.047, \mathrm{SE}=0.009, \mathrm{p}$ $<0.01$ ) (Table 6, column 13).

\footnotetext{
${ }^{16}$ Because ISO adopters had lower death rates, the results on sales, employment, and total payroll would be slightly more positive for ISO adopters if non-surviving firms were included in the analysis.
} 
Because firms can take one to two years to adopt all aspects of the standard before becoming certified (Stevenson and Barnes 2002), some benefits of adopting ISO 9001 might begin to accrue even before certification. This, however, would represent a potential bias against our finding significant improved performance between the pre- and post-periods, and would imply that our difference-in-differences results might in fact be underestimating the true effects of adoption.

\subsubsection{Evaluation extensions}

Extending our analysis to some additional and more nuanced effects of ISO 9001 adoption, we consider two additional outcome measures and explore whether the effects of ISO 9001 differ across subsets of our sample. We also examine whether the correlations reported above might be due to the possibility that financial distress could deter ISO adoption and affect firm survival or our financial outcomes.

Our first extension examines whether ISO 9001 adoption is associated with a greater likelihood of eliminating all injury-related workers' compensation claims. We estimate a probit model to predict which employers reported zero injuries (technically, zero workers' compensation claims) in all years after the match year, using the full set of 471 matched pairs of firms. We collapsed our panel data into a cross section, coding the dependent variable " 1 " for firms that reported no injuries all years after the match year and " 0 " for firms that reported at least one injury after the match year. We included as controls the $\log$ of each firm's average employment and average payroll for post-match years, region dummies, and industry dummies. Recall that the matched set of adopters and non-adopters used in this regression (and all regressions reported in Tables 5 and 6) had similar (and statistically indistinguishable) injury rates during the years prior to the match. In contrast to the negative binomial results discussed above, the results of this cross-sectional probit analysis indicate that ISO 9001 adopters were subsequently five percentage points more likely to report no injuries (Table 7), a large effect given that the mean of the dependent variable is $28 \%$. Taken together, these three sets of results provide limited support for Hypothesis 4 , that ISO adoption lowers injury rates and costs, but no support for Hypothesis 4', that adoption worsens these measures of occupational safety and health. 
Our second extension addresses injury rates in a more nuanced way. Specifically, we examine whether adopters and non-adopters subsequently differed with respect to two particular types of injuries: serious sudden-onset injuries (as typically occur following industrial accidents), and serious cumulative injuries (which could result from more repetitive work). This sub-analysis is motivated by the concern that ISO adoption might occasion more repetitive work, leading to an increase in the rate of cumulative injuries. WCIRB data has only one category for "serious" injuries, being those associated with at least $\$ 2,000$ in costs. These conditional fixed effects negative binomial models include controls for employment, payroll, sales, average occupational riskiness, calendar years, and dummies to denote the number of years until or since the match year. The results indicate no change in sudden-onset injury rates $(\mathrm{b}=-0.064 ; \mathrm{SE}=0.087)$ between adopters and matched controls (results are not shown to conserve space). But the regression predicting the number of serious cumulative injuries yields an incident rate ratio of $0.61(\mathrm{~b}=-0.495 ; \mathrm{SE}=0.314)$ for has adopted ISO 9001, which constitutes an economically meaningful, albeit not statistically significant, decline among adopters. Further research is warranted to explore the circumstances under which ISO 9001 adoption might help to reduce serious cumulative injuries.

A third extension examines the extent to which the effects of ISO 9001 adoption differ between larger and smaller firms. If their managers have less formal education and less experience, adopting ISO 9001 might lead to more learning at smaller firms. Having fewer resources to invest in advertising and branding, smaller firms might also find it more difficult to establish a reputation for high-quality products and services and thus be expected to realize greater signaling benefits from ISO 9001 certification.

To test whether ISO adoption was more beneficial to smaller firms, we split the sample based on preadoption employment. For each adopter and matched control pair, we calculated the average employment during the two years prior to the adoption (or match) year. We categorized these two groups: matched pairs with average employment levels below the sample median, and matched pairs with average employment levels above the median. We created dummy variables for these two groups and estimated fully-interacted fixed-effects models in which all variables from the fixed-effects models reported in 
Table 6 were interacted with each of these two dummies.

The results are striking (see Table 8). Growth in employment, sales, and payroll was greater for smaller than for larger ISO adopters (compared to their respective peers), and the differences are economically and statistically significant. These results strongly suggest that more is learned, or the ability to signal quality is more greatly improved, or both, in smaller than in larger firms that adopt ISO 9001.

\subsubsection{Limitations and robustness tests}

Our study has several limitations including our inability to (1) acquire data on all determinants of adoption that we would like to include, and (2) conclusively interpret our difference-in difference results as causal effects. Here we describe several robustness tests of our propensity score specification, matching technique, and evaluation model, and highlight some limitations of our study.

Financial stress. If financially stronger firms both adopt ISO 9001 more often and have better financial outcomes and survival rates, then our inability to find data on the financial strength of our sample firms might result in omitted variable bias. We could not obtain accounting data such as profit to measure financial strength because many of the single-plant firms in our sample are privately held. Fortunately, in the NETS database are two measures of financial stress issued by Dun \& Bradstreet (D\&B) that are tailored to smaller firms, and which we were able to obtain for a subset of our sample. A company's PAYDEX score is a "dollar-weighted numerical indicator of how a firm paid its bills over the past year, based on trade experiences reported to D\&B by various vendors. The D\&B PAYDEX Score ranges from 1 to 100, with higher scores indicating better payment performance."17 The Composite Credit Appraisal rating, scored from 1 (worst) through 4 (best), "reflects D\&B's overall assessment of . . . creditworthiness. The Composite Credit Appraisal is based on D\&B analysis of company payments, financial information, public records, business age and other important factors (when available)."18

17 Dun \& Bradstreet, “Glossary of D\&B Terms: PAYDEX Score,” https:/www.dnb.com/product/birgloss.htm\#p (accessed June 3, 2009).

18 Dun \& Bradstreet, "Glossary of D\&B Terms: Key to the D\&B Rating," 
We examined whether financial stress was less common in ISO adopters than in comparison firms by running t-tests on each of our matched samples for the two continuous measures - minimum and maximum PAYDEX scores in the year prior to adoption (or match) - to determine whether these variables were already balanced in our matched sample (Rosenbaum and Rubin 1985). We also conducted Wilcoxon rank-sum tests of the ordinal Composite Credit Appraisal score. Somewhat to our surprise, adopters and comparison firms had similar distributions of all three financial stress metrics (see Table A5 in the On-line Appendix).

Finally, we assessed whether financial stress is a significant predictor of adoption by re-estimating our selection probit model but also including the following alternative measures, each lagged one year: (1) minimum PAYDEX score; (2) maximum PAYDEX score; (3) Composite Credit Appraisal score; and (4) a series of dummies for each Composite Credit Appraisal score. The results of these four models (reported in Table A6 in the On-line Appendix) were consistent in yielding no evidence that financial stress is associated with the propensity to adopt ISO 9001. In summary, because t-tests and rank-sum tests indicate that financial stress is balanced between our matched treatment and control groups, and probit results provide no evidence that financial stress is a significant predictor of ISO 9001 adoption, we believe our results are unlikely to be biased by financial stress.

Growth prospects. A concern with the causal interpretation of these results is that employers with better growth prospects might both adopt ISO 9001 and have higher post-adoption growth rates. We have three reasons to doubt the importance of this alternative causality. First, we control for employer fixed effects, industry-specific time trends, and a host of observable characteristics (via the matched comparison group). Second, although we do not match on pre-existing sales trends, they are nonetheless quite similar between our matched adopters and comparison firms. Finally, in our matched sample, we did not find that firms with poor credit ratings were any less likely to adopt ISO 9001. Thus, we have no evidence that adopting firms had better growth prospects prior to ISO 9001 adoption. 
Safety practices. Lacking measures of safety practices such as safety committees, our estimates might be biased if safety practices affect our outcomes and are correlated with ISO 9001 adoption. But because our matched adopters and non-adopters are in the same industries and regulatory regime (CalOSHA), it is unclear why omitted safety practices should be correlated with ISO 9001 adoption unless adoption strengthened these practices. For example, the review of all standard procedures mandated by ISO 9001 should include a review of safety-related procedures. If ISO 9001 certification does a better job of enforcing or encouraging this review than Cal-OSHA regulations (which are rarely enforced by CalOSHA), omission of such endogenous safety practices is appropriate. Intuitively, if improved compliance with Cal-OSHA regulations was both an effect of ISO 9001 and lowered injury rates, we would underestimate the total causal effect of ISO 9001 on injuries if we attributed the decline in injuries to an exogenous improvement in regulatory compliance.

Restricting matched controls to never-adopters. The matching technique described above restricted control candidates to firms that never adopted ISO 9001 during the sample period. As a robustness test, we developed another matched sample, relaxing this limitation to allow all firms that had not yet adopted to serve as comparison firms, including those that would adopt in a future year during the sample period (but only until their adoption year, after which we dropped them as controls). This allowed, for example, an adopter in 1999 to be matched to firm that was a non-adopter in 1999 but subsequently adopted in 2002 (in which case we would include this control firm's observations only until 2002). In cases in which eventual-adopters were identified as matched controls, we replicated their data in our dataset to enable us to use them both as controls and adopters. In the regressions that relied on this alternative matched sample, we clustered standard errors by firm to account for the non-independence this introduced. The results of the regression models based on this alternative matched sample were nearly identical to those based on our primary matched sample.

Potential for predominant industries to drive treatment results. Nearly half the firms in our matched samples were in just two industries, electronic and electric products and final metal products. To explore the extent to which our results were driven by these predominant industries, we categorized the 
matched sample into two groups: matched pairs that belong to either of these two predominant industries, and matched pairs that belong to other industries. We created two dummy variables to identify these two subsets, and estimated fully-interacted fixed-effects models by interacting all variables from our main fixed-effects models with each of these dummies. Although most results of these models (not shown to conserve space) indicated the effects of ISO 9001 adoption to be quite similar between the two industry groups, the analysis did reveal one interesting difference. While we found that adopters in both sets of industries experienced significant increases in payroll and wages (compared to their peers), growth was greater for adopters in the two predominant industries (compared to their peers) than for adopters in the other industries (compared to their peers). Further research might explore how and why the effects of adoption differ across industries.

\section{Conclusion}

Our results are readily summarized. First, ISO adopters had far lower organizational death rates than matched firms within their industries. Second, sales and employment grew substantially more rapidly post certification at firms that adopted ISO 9001 than at matched firms. Third, total payroll and (to a lesser extent) annual earnings per employee grew substantially more rapidly post certification at firms that adopted ISO 9001 than at matched firms. Fourth, some benefits of ISO 9001 adoption were much more pronounced in smaller firms than in larger firms. Finally, ISO 9001 adopters already had slightly lower than average injury costs at the time of adoption, and we found no evidence that this gap widened or narrowed post adoption. Adopters were more likely to report no injuries for workers' compensation in the years following adoption. We found no differences in the number of injuries between adopters and matched comparison firms that reported a positive number of injuries.

Our finding that ISO 9001 certification benefits employers bolsters prior research on ISO 9001 (e.g., Corbett et al. 2005; Terlaak and King 2006) and related programs such as TQM and quality awards (e.g., Hendricks and Singhal 1996, 1997, 2001b). Our results are particularly credible because we analyze a 
larger sample of ISO certifications than almost any previous study, have performance data at the workplace level (unlike many previous studies that examine how ISO certification at a single plant affects the financial performance of a multi-plant organization), measure performance using third-party (rather than self-reported) data, use a panel dataset that enables us to measure performance over time, and develop carefully matched sets of non-adopters. Our results regarding the benefits of ISO 9001 certification for employment, payroll, and average annual earnings are new.

Critics of ISO 9001 and related programs who express concern that benefits to employers derive largely from the deskilling and routinization of tasks hypothesize that employer gains consequently come at the expense of employees' earnings. Our results showing total payroll to rise faster than employment, which implies an increase in average annual earnings, do not provide evidence of deskilling.

Non-experimental data cannot definitively attribute the better outcomes experienced by ISO 9001 adopters relative to matched controls to adoption, as opposed to unobserved advantages that might account for both ISO adoption and better outcomes. But the strength and consistency of our findings leads us to shift our own priors in favor of the hypothesis that ISO 9001 adoption is more beneficial than we had anticipated.

Future research should investigate the causal mechanisms that might account for the patterns we discovered, unpacking, for example, the relative importance of managerial learning, signals, and incentives. For example, longitudinal product-level data on internal quality metrics (e.g., scrap rates), external quality metrics (e.g., warranty claims), and product mark-ups could be used by researchers to distinguish situations in which ISO 9001 spurs a learning process that improves quality from situations in which ISO 9001 serves largely to signal pre-existing high quality levels that had previously been difficult to convey credibly in the marketplace.

Researchers with access to detailed cost data could examine whether ISO 9001 adoption reduces waste and defects, which would be reflected in the cost of goods sold. Detailed financial data could enable researchers to compare the costs of implementing ISO 9001, including those of developing and implementing quality policies and procedures and training programs, to the additional sales revenue that 
certification might prompt. Detailed quality and cost data might enable researchers to theorize about when ISO 9001 is more likely to spur managerial learning, send credible signals, or create stronger incentives for firms to improve quality.

As important, this study has examined single-plant manufacturing firms in California, a well known hub of innovation in which manufacturing is roughly twice as likely to be high-tech as in the rest of the nation. It is important to measure the degree to which these results generalize to multi-plant firms, other sectors, and other regions. If the relationships we report hold up in other settings, and additional evidence can support their causal interpretation, such findings would have implications for managers, organizational scholars, and public policy.

For managers, the lessons are that the process of ISO 9001 certification appears to be valuable to most adopters. We cannot be sure how broadly these lessons apply to non-adopters, but the considerable benefits of adoption (e.g., roughly $10 \%$ increases in sales) suggest that far more employers could benefit from ISO 9001 adoption than currently do. Our results further suggest that smaller enterprises are particularly likely to benefit from adoption.

The substantial improvement in outcomes post ISO 9001 adoption also has lessons for organizational scholars. Some academics have characterized quality programs such as ISO 9001 as management fads unlikely to benefit employers or employees (see Abrahamson 1996 and citations in Staw and Epstein 2000). Fashion might well play a role in the adoption of many management practices, but our results indicate that ISO 9001 appears to deliver value for many organizational stakeholders.

We would not anticipate the large benefits that we measure if potential customers could already see product or service quality, if managers already understood how to achieve higher productivity and quality cost-effectively, and if managers could capture the returns to any improvements in quality or productivity (Levine 1995: ch. 3). The substantial increases in employment, total payroll, and sales that we estimate are consistent with at least one of these market imperfections slowing the spread of quality programs. These results consequently also support arguments that public policy should promote quality programs, for example, by subsidizing employee training or educating managers about the value of such programs 
(e.g., Helper and Levine 1995).

\section{References}

Abrahamson, E. 1996. Management fashions. Academy of Management Review 21(1): 254-285.

Adler, P. S., B. Goldoftas, D. Levine. 1997. Ergonomics, employee involvement, and the Toyota Production System: A case study of NUMMI's 1993 model introduction. Industrial and Labor Relations Review 50(3): 416-437.

Barbeau, E., C. Roelofs, R. Youngstrom, G. Sorensen, A. Stoddard, A. D. LaMontagne. 2004. Assessment of occupational safety and health programs in small businesses. American Journal of Industrial Medicine 45: 371-379.

Barber, B. M., J. D. Lyon. 1996. Detecting abnormal operating performance: The empirical power and specification of test statistics. Journal of Financial Economics 41(3): 359-399.

Benner, M. J., F. M. Veloso. 2008. ISO 9000 practices and financial performance: A technology coherence perspective. Journal of Operations Management 26: 611-629.

Blundell, R., M. Costa Dias, C. Meghir, J. Van Reenen. 2004. Evaluating the employment impact of a mandatory job search program. Journal of the European Economic Association 2(4): 569-606.

Brenner, M. D., D. Fairris, J. W. Ruser. 2004. 'Flexible' work practices and occupational safety and health: Exploring the relationship between cumulative trauma disorders and workplace transformation. Industrial Relations 43(1): 242-266.

Conti, R., J. Angelis, C. Cooper, B. Faragher, C. Gill. 2006. The effects of lean production on worker job stress. International Journal of Operations \& Production Management 26(9): 1013-1038.

Corbett, C. J., A. M. Luca, H-N Pan. 2003. Global perspectives on global standards: A 15-economy survey of ISO 9000 and ISO 14000. ISO Management Systems (Jan-Feb). http://www.iso.org/iso/en/iso9000-14000/articles/surveysandoverviews.html.

Corbett, C. J., M. J. Montes-Sancho, D. A. Kirsch. 2005. The financial impact of ISO 9000 certification in the United States: An empirical analysis. Management Science 51(7): 1046-1059.

Dehejia, R. H., S. Wahba. 1999. Causal effects in nonexperimental studies: Reevaluating the evaluation of training programs. Journal of the American Statistical Association 94(448): 1053-1062.

Docking, D. S., R. J. Dowen. 1999. Market interpretation of ISO 9000 registration. Journal of Financial Research 22(2): 147-160.

Easton, G. S., S. L. Jarrell. 1998. The effects of Total Quality Management on corporate performance: An empirical investigation. Journal of Business 71(2): 253-307.

Eichler, M., M. Lechner. 2002. An evaluation of public employment programmes in the East German state of Sachsen-Anhalt. Labour Economics 9: 143-186.

Fairris, D., M. D. Brenner. 2001. Workplace transformation and the rise in cumulative trauma disorders: Is there a connection? Journal of Labor Research 22(1): 15-28. 
Ferguson, W. 1996. Impact of the ISO 9000 series standards on industrial marketing. Industrial Marketing Management 25(4): 305-310.

Galiani, S., P. Gertler, E. Schargrodsky. 2005. Water for life: The impact of the privatization of water services on child mortality. Journal of Political Economy 113(1): 83-120.

Greenaway, D., J. Gullstrand, R. Kneller. 2005. Exporting may not always boost firm productivity. Review of World Economics 141(4): 561-582.

Häversjö, T. 2000. The financial effects of ISO 9000 registration for Danish companies. Managerial Auditing Journal 15(1/2): 47-52.

Heckman, J. J., H. Ichimura, P. E. Todd. 1997. Matching as an econometric evaluation estimator: Evidence from evaluating a job training programme. The Review of Economic Studies 64(4): 605654.

Heckman, J. J., H. Ichimura, P. Todd. 1998. Matching as an econometric evaluation estimator. The Review of Economic Studies 65(2): 261-294.

Helper, S., D. I. Levine. 1995. A quality policy for America. Contemporary Policy Issues 13(2): 26-37.

Helper, S., D. I. Levine, E. Bendoly. 2002. Employee involvement and pay at American auto suppliers. Journal of Economics \& Management Strategy 11(2): 329-377.

Hendricks, K. B., V. R. Singhal. 1996. Quality awards and the market value of the firm: An empirical investigation. Management Science 42(3): 415-436.

Hendricks, K. B., V. R. Singhal. 1997. Does implementing an effective TQM program actually improve operating performance? Empirical evidence from firms that have won quality awards. Management Science 43(9): 1258-1274.

Hendricks, K. B., V. R. Singhal. 2001a. Firm characteristics, Total Quality Management, and financial performance: An empirical investigation. Journal of Operations Management 19: 269-285.

Hendricks, K. B., V. R. Singhal. 2001b. The long-run stock price performance of firms with effective TQM programs as proxied by quality award winners. Management Science 47(3): 359-368.

Heras, I., P. M. Gavin, M. C. Dick. 2002. ISO 9000 registration's impact on sales and profitability: A longitudinal analysis of performance before and after certification. International Journal of Quality Reliability Management 19(6): 774-791.

Huarng, E., C. Horng, C. Chen. 1999. A study of ISO 9000 process, motivation, and performance. Total Quality Management 10(7): 1009-1025.

Huttunen, K. 2007. The effect of foreign acquisition on employment and wages: Evidence from Finnish establishments. Review of Economics \& Statistics 89 (3): 497-509.

King, A. A., M. J. Lenox. 2001. Lean and green? An empirical examination of the relationship between lean production and environmental performance. Production and Operations Management 10(3): 244-256.

Koc, T. 2007. The impact of IS0 9000 quality management systems on manufacturing. Journal of Materials Processing Technology 186: 207-213.

Landau, K., H. Peters. 2006. Ergonomic demands in automotive component inspection tasks. Occupational Ergonomics 6: 95-105. 
Levine, D. I. 1992. Can wage increases pay for themselves? Tests with a productive function. Economic Journal 102: 1102-1115.

Levine, D. I. 1995. Reinventing the Workplace. Washington DC: The Brookings Institute.

Lindbeck, A., D. A. Snower. 1986. Wage setting, unemployment and insider-outsider relations. American Economic Review 76: 235-239.

Marcus, A. A., M. L. Nichols. 1999. On the edge: Heeding the warnings of unusual events. Organization Science 10(4): 482-499.

McGuire, S. J., D. M. Dilts. 2008. The financial impact of standard stringency: An event study of successive generations of the ISO 9000 standard. International Journal of Production Economics 113: 3-22.

Naveh, E., M. Erez. 2006. Innovation and attention to detail in the quality improvement paradigm. Management Science 50(11): 1576-1586.

Naveh, E., A. Marcus. 2007. Financial performance, ISO 9000 standard, and safe driving practices effects on accident rate in the U.S. motor carrier industry. Accident Analysis \& Prevention 39(4): 731742 .

O'Connor, P. 2005. Do management standards bring success? ISO 9000 firms grew rapidly in Oregon. Oregon Labor Market Information System, October 27. http://www.qualityinfo.org/olmisj/ArticleReader?itemid=00004604\#seg0004, accessed March 16, 2008 .

Qian, Y. 2007. Do national patent laws stimulate domestic innovation in a global patenting environment? A cross-country analysis of pharmaceutical patent protection, 1978-2002. Review of Economics \& Statistics 89(3): 436-453.

Rosenbaum, P. R., D. B. Rubin. 1983. The central role of the propensity score in observational studies for causal effects. Biometrika 70(1): 41-55.

Rosenbaum, P. R., D. B. Rubin. 1985. Constructing a control group using multivariate matched sampling methods that incorporate the propensity score. The American Statistician 39: 33-38.

Sharma, D. S. 2005. The association between ISO 9000 certification and financial performance. The International Journal of Accounting 40: 151-172.

Simmons, B. L., M. A. White. 1999. The relationship between ISO 9000 and business performance: Does registration really matter? Journal of Managerial Issues 11(3): 330-343.

Smith, J. A., P. E. Todd. 2005. Does matching overcome LaLonde's critique of nonexperimental estimators? Journal of Econometrics 125(1-2): 305-353.

Spence, M. 1973. Job market signaling. Quarterly Journal of Economics 87: 355-374.

Staw, B. M., L. D. Epstein. 2000. What bandwagons bring: Effects of popular management techniques on corporate performance, reputation, and CEO pay. Administrative Science Quarterly 45(3): 523556.

Stevenson, T. H., F. C. Barnes. 2002. What industrial marketers need to know now about ISO 9000 certification: A review, update, and integration with marketing. Industrial Marketing Management 31: 695-703. 
Terlaak, A. A., A. A. King. 2006. The effect of certification with the ISO 9000 Quality Management Standard: A signaling approach. Journal of Economic Behavior \& Organization 60: 579-602.

Toffel, M. W. 2000. Anticipating greener supply chain demands: One Singapore company's journey to ISO 14001. In R. Hillary (Ed.), ISO 14001: Case Studies and Practical Experiences. Sheffield, UK: Greenleaf Publishing.

Villalonga, B. 2004. Does diversification cause the 'diversification discount'? Financial Management 33 (2): 5-27.

Wayhan, V. B., E. L. Balderson. 2007. TQM and financial performance: What has empirical research discovered? Total Quality Management 18(4): 403-412.

Williamson, A., S. Boufous. 2007. A data-matching study of the role of fatigue in work-related crashes. Transportation Research: Part F 10(3): 242-253.

Wokutch, R. E. 1992. Worker Protection, Japanese Style. Ithaca, NY: ILR Press. 
Table 1.

Sample characteristics

\begin{tabular}{|c|c|c|c|c|c|c|}
\hline \multirow[b]{2}{*}{ Panel A. Industry } & \multicolumn{2}{|c|}{$\begin{array}{l}\text { Entire sample for } \\
\text { adoption models }\end{array}$} & \multicolumn{2}{|c|}{$\begin{array}{c}\text { Matched sample } \\
\text { for survival models }\end{array}$} & \multicolumn{2}{|c|}{$\begin{array}{l}\text { Matched sample for } \\
\text { treatment models }\end{array}$} \\
\hline & Firms & $\%$ & Firms & $\%$ & Firms & $\%$ \\
\hline Agriculture industry & 22 & 0.1 & 2 & 0.2 & & \\
\hline Construction or erection industry & 1,042 & 5.6 & 10 & 0.8 & 8 & 0.9 \\
\hline Manufacturers of electronic $\&$ electrical products & 960 & 5.1 & 360 & 28.9 & 256 & 27.2 \\
\hline Manufacturers of final metal products & 1,461 & 7.8 & 250. & 20.1 & 204. & 21.7 \\
\hline Manufacturers of food products & 22 & 0.1 & & & & \\
\hline Manufacturers of intermediate metal products & 401 & 2.1 & 142 & 11.4 & 110 & 11.7 \\
\hline Manufacturers of paper products & 363 & 1.9 & 22 & 1.5 & 18 & 1.9 \\
\hline Manufacturers of plastic \& rubber products & 277 & 1.5 & 84 & 6.8 & 62 & 6.6 \\
\hline Manufacturers of textile, cloth \& leather products & 199 & 1.1 & 18 & 1.5 & 12 & 1.3 \\
\hline Manufacturers of wood products & 61 & 0.3 & 4. & 0.3 & 2 & 0.2 \\
\hline Manufacturers, other & 433 & 2.3 & 72 & 5.8 & 62 & 6.6 \\
\hline Mercantile industry & 2,009 & 10.7 & 132 & 10.6 & 106 & 11.3 \\
\hline Other industry & 1,427 & 7.6 & 58 & 4.7 & 34 & 3.6 \\
\hline Professional \& clerical services industry & 10,088 & 53.8 & 90 & 7.2 & 68 & 7.2 \\
\hline Total firms & 18,765 & $100 \%$ & 1,244 & $100 \%$ & 942 & $100 \%$ \\
\hline Panel B. Geographic Region & Firms & $\%$ & Firms & $\%$ & Firms & $\%$ \\
\hline Bay Area region & 3,501 & 18.7 & 231 & 18.6 & 178 & 18.9 \\
\hline Central Coast region & 1,402 & 7.5 & 94 & 7.6 & 63 & 6.7 \\
\hline Central Valley region & 1,338 & 7.1 & 24 & 2.0 & 15 & 1.6 \\
\hline Los Angeles Basin region (outside LA County) & 2,754 & 14.7 & 315 & 25.3 & 248 & 26.3 \\
\hline Los Angeles County region & 5,649 & 30.1 & 417 & 33.5 & 322 & 34.2 \\
\hline Other California region & 933 & 5.0 & 21. & 1.7 & 12 & 1.3 \\
\hline Sacramento region & 1,001 & 5.3 & 19 & 1.5 & 16 & 1.7 \\
\hline San Diego County region & 2,187 & 11.7 & 123 & 9.9 & 88 & 9.3 \\
\hline Total firms & 18,765 & $100 \%$ & 1,244 & $100 \%$ & 942 & $100 \%$ \\
\hline Panel C. Adoption Year & Firms & $\%$ & Firms & $\%$ & Firms & $\%$ \\
\hline 1994 & 15 & 0.1 & 12 & 1.0 & 12 & 1.3 \\
\hline 1995 & 24 & 0.1 & 24. & 2.0 & 24 & 2.6 \\
\hline 1996 & 34 & 0.2 & 30 & 2.4 & 26 & 2.8 \\
\hline 1997 & 47 & 0.3 & 43 & 3.5 & 41 & 4.4 \\
\hline 1998 & 81 & 0.4 & 71 & 5.8 & 66 & 7.0 \\
\hline 1999 & 79 & 0.4 & 70 & 5.7 & 65 & 6.9 \\
\hline 2000 & 90 & 0.5 & 75 & 6.1 & 68 & 7.2 \\
\hline 2001 & 161 & 0.9 & 118 & 9.6 & 105. & 11.2 \\
\hline 2002 & 129 & 0.7 & 83 & 6.7 & 64 & 6.8 \\
\hline 2003 & 152 & 0.8 & 96 & 7.8 & & \\
\hline 2004 & 70 & 0.4 & & & & \\
\hline 2005 & 34 & 0.2 & & & & \\
\hline Total adopters & 916 & & 622 & & 471 & \\
\hline Non-adopters & 17,849 & 95.1 & 622 & 49.5 & 471 & 50.0 \\
\hline Total firms & 18,765 & $100 \%$ & 1,244 & $100 \%$ & 942 & $100 \%$ \\
\hline
\end{tabular}


Table 2.

\section{Descriptive statistics of entire sample (used in selection analysis)}

\begin{tabular}{|c|c|c|c|c|c|}
\hline Variable & Description & Mean & SD & Min & $\operatorname{Max}$ \\
\hline $\begin{array}{l}\text { Adopted ISO } 9001 \text { this } \\
\text { year }\end{array}$ & $\begin{array}{l}\text { Dummy coded " } 1 \text { " in the firm-year in which a firm } \\
\text { adopted ISO } 9001 \text {, and " } 0 \text { " otherwise. }\end{array}$ & 0.0054 & 0.0731 & 0 & 1 \\
\hline Log injury costs $1 \&-2$ & $\begin{array}{l}\text { Natural log of } \$ 1,000 \text { plus the average of one- and } \\
\text { two-year lags of total annual workers' } \\
\text { compensation injury costs, in dollars. To reduce the } \\
\text { effect of outliers, we took the log of injury costs } \\
\text { after adding } \$ 1,000 \text {. }\end{array}$ & 7.51 & 1.23 & 6.91 & 17.14 \\
\hline $\log _{\text {injury rate }}-1 \&-2$ & $\begin{array}{l}\text { Natural log of } 1 \text { plus the average of one- and two- } \\
\text { year lags of the annual number of injuries reported } \\
\text { for workers' compensation. }\end{array}$ & 0.33 & 0.60 & 0 & 8.33 \\
\hline Log payroll $_{-1 \&-2}$ & $\begin{array}{l}\text { Natural log of the average of one- and two-year lags } \\
\text { of annual payroll, in dollars. To minimize the impact } \\
\text { of outliers, we omitted very small annual payroll } \\
\text { values (less than } \$ 5,000 \text { ) and instances of rapid } \\
\text { growth or shrinkage in payroll (as when the ratio of } \\
\text { current exposure to its one-year lag was outside the } \\
\text { range of } 0.5 \text { to 2). }\end{array}$ & 12.13 & 1.29 & 8.52 & 21.50 \\
\hline Log employment $_{-1 \&-2}$ & $\begin{array}{l}\text { Natural log of the average of one- and two-year lags } \\
\text { of number of employees. } \\
\text { To minimize the impact of outliers, we omitted } \\
\text { instances of rapid growth or shrinkage in } \\
\text { employment (as when the ratio of current } \\
\text { employment to its one-year lag was outside the } \\
\text { range of } 0.5 \text { to 2). }\end{array}$ & 2.07 & 1.01 & 0 & 8.71 \\
\hline Log sales $_{-1 \&-2}$ & $\begin{array}{l}\text { Natural log of the average of one- and two-year lags } \\
\text { of annual firm sales, in dollars. }\end{array}$ & 13.63 & 1.32 & 0 & 19.82 \\
\hline $\begin{array}{l}\text { Log average } \\
\text { occupational riskiness } \\
1 \&-2\end{array}$ & $\begin{array}{l}\text { Natural log of the average of one- and two-year lags } \\
\text { of a firm's average annual hazard per payroll dollar. } \\
\text { A firm's annual average hazard is the sum across all } \\
\text { occupation classes of the following: the payroll } \\
\text { dollars in each occupation class multiplied by the } \\
\text { WCIRB Pure Premium Rate for each occupation } \\
\text { class. We divide this sum by the firm's payroll that } \\
\text { year. }\end{array}$ & 0.47 & 0.90 & -1.71 & 3.12 \\
\hline
\end{tabular}

$\mathrm{N}=158,170$ firm-year observations. The sample includes all non-adopters in all years and all adopters before and during their adoption year, provided they have observations with complete data for the model. Variables subscripted $-1 \&-2$ are averages of 1- and 2- year lags. 
Table 3.

Predicting adoption of ISO 9001

Dependent variable: Adopts ISO 9001 this year (dummy)

\begin{tabular}{|c|c|c|}
\hline & $\begin{array}{c}\text { Probit } \\
\text { coefficients }\end{array}$ & $100 \times$ marginal effects ${ }^{a}$ \\
\hline Log sales $_{-1 \&-2}$ & $\begin{array}{l}0.0961 * * * \\
{[0.0202]}\end{array}$ & $0.01580 * * *$ \\
\hline $\log _{\text {payroll }}-1 \&-2$ & $\begin{array}{l}0.2775 * * * \\
{[0.0264]}\end{array}$ & $0.04560 * * *$ \\
\hline Log employment $_{-1 \&-2}$ & $\begin{array}{c}0.0054 \\
{[0.0277]}\end{array}$ & 0.00088 \\
\hline $\log _{\text {injury }}$ costs $_{-1 \&-2}$ & $\begin{array}{l}-0.0318^{* *} \\
{[0.0146]}\end{array}$ & $-0.00522 * *$ \\
\hline $\log _{\text {injury rate }} 1 \&-2$ & $\begin{array}{c}0.0128 \\
{[0.0311]}\end{array}$ & 0.00211 \\
\hline Log average occupational riskiness $_{-1 \&-2}$ & $\begin{array}{l}-0.3468 * * * \\
{[0.0350]}\end{array}$ & $-0.05704 * * *$ \\
\hline Observations (firm-years) & 158,170 & \\
\hline Firms & 18,765 & \\
\hline Pseudo R squared (McFadden's) & 0.29 & \\
\hline Wald Chi squared & $1696.53 * * *$ & \\
\hline
\end{tabular}

Brackets contain robust standard errors clustered by firm. $* * * \mathrm{p}<0.01,{ }^{* *} \mathrm{p}<5 \%,{ }^{*} \mathrm{p}<0.10$. Variables subscripted $-1 \&-2$ are averages of 1- and 2- year lags. Additional controls include year dummies (19952005), 7 region dummies, and 14 industry dummies. Sample includes adopters before and in their adoption year and all years for non-adopters.

a $100 \times$ marginal effects $=$ change in $\%$ adopting each year associated with a 1 point increase in the independent variable. 
Table 4.

Summary statistics of matched sample used for analysis of treatment

\begin{tabular}{|c|c|c|c|c|c|}
\hline Variable & Description & Mean & SD & Min & Max \\
\hline $\begin{array}{l}\text { Has adopted ISO } \\
9001\end{array}$ & $\begin{array}{l}\text { Dummy coded " } 1 \text { " if the firm has adopted ISO } \\
9001 \text { in a previous year, and "0" otherwise. }\end{array}$ & 0.19 & 0.39 & 0 & 1 \\
\hline $\begin{array}{l}\text { Has adopted ISO } \\
9001 \times \text { post-years } \\
1 / 2 / 3\end{array}$ & $\begin{array}{l}\text { Dummy coded " } 1 \text { " if the firm initially adopted } \\
\text { ISO } 90011 \text { to } 3 \text { years ago, and " } 0 \text { " otherwise. }\end{array}$ & 0.12 & 0.33 & 0 & 1 \\
\hline $\begin{array}{l}\text { Has adopted ISO } \\
9001 \times \text { post-years } \\
4 / 5 / 6\end{array}$ & $\begin{array}{l}\text { Dummy coded " } 1 \text { " if the firm initially adopted } \\
\text { ISO } 90014 \text { to } 6 \text { years ago, and " } 0 \text { " otherwise. }\end{array}$ & 0.05 & 0.22 & 0 & 1 \\
\hline $\begin{array}{l}\text { Has adopted ISO } \\
9001 \times \text { post-years } \\
7 / 8 / 9\end{array}$ & $\begin{array}{l}\text { Dummy coded " } 1 \text { " if the firm initially adopted } \\
\text { ISO } 90017 \text { to } 9 \text { years ago, and " } 0 \text { " otherwise. }\end{array}$ & 0.01 & 0.10 & 0 & 1 \\
\hline Injury costs & $\begin{array}{l}\text { Annual workers' compensation injury costs in } \\
\text { dollars. }^{\text {a }}\end{array}$ & 22,129 & 65,434 & 0 & $1,340,663$ \\
\hline Log injury costs & $\begin{array}{l}\text { Natural log of } \$ 1,000 \text { plus total annual workers' } \\
\text { compensation injury costs, in dollars. }{ }^{a}\end{array}$ & 8.25 & 1.72 & 6.91 & 14.11 \\
\hline Injury rate & $\begin{array}{l}\text { Annual number of injuries reported to workers' } \\
\text { compensation. }^{\text {a }}\end{array}$ & 3.55 & 8.72 & 0 & 256 \\
\hline Log injury rate & Natural $\log$ of 1 plus the injury rate. ${ }^{a}$ & 0.92 & 0.96 & 0 & 5.55 \\
\hline Log payroll & Natural log of annual payroll, in dollars. ${ }^{\mathrm{b}, \mathrm{c}}$ & 13.72 & 1.03 & 10.08 & 17.99 \\
\hline Log employment & Natural log of the number of employees. ${ }^{c}$ & 3.28 & 0.98 & 0 & 6.21 \\
\hline Log wage & $\begin{array}{l}\text { Natural log of the ratio of payroll to } \\
\text { employment. }\end{array}$ & 10.44 & 0.77 & 8.86 & 16.80 \\
\hline Log sales & Natural log of annual firm sales. & 14.92 & 1.14 & 9.24 & 19.52 \\
\hline $\begin{array}{l}\text { Log average } \\
\text { occupational } \\
\text { riskiness }\end{array}$ & $\begin{array}{l}\text { Natural log of a firm's average annual hazard per } \\
\text { payroll dollar. A firm's annual average hazard is } \\
\text { the sum across all occupation classes of the } \\
\text { following: the payroll dollars in each occupation } \\
\text { class multiplied by the WCIRB Pure Premium } \\
\text { Rate for each occupation class. We divide this } \\
\text { sum by the firm's payroll that year. }\end{array}$ & 0.80 & 0.62 & -1.51 & 2.04 \\
\hline
\end{tabular}

$\mathbf{N}=8420$ firm-year observations from 942 firms during 1993-2003.

${ }^{a}$ Missing values for injury costs are converted to zeros if data exists for exposure in that year.

${ }^{\mathrm{b}}$ To minimize the impact of outliers, we omitted very small annual payroll values (less than $\$ 5,000$ ).

${ }^{\mathrm{c}}$ To minimize the impact of firms that were rapidly growing or shrinking, we omitted instances in which the ratio of current year's value to its one-year lag was outside the range of 0.5 to 2 .

${ }^{\mathrm{d}}$ To minimize the impact of outliers, we omitted firm-years with very low average annual wages (less than $\$ 7,020$, calculated as 20 hours per week $* 52$ weeks per year $* \$ 6.75$ [California minimum wage as of Jan 2002]). 
Table 5.

Employer outcomes

\begin{tabular}{|c|c|c|c|c|c|c|}
\hline & (1) & (2) & (3) & (4) & (5) & $(6)$ \\
\hline Dependent variable: & \multicolumn{2}{|c|}{ Log employment } & \multicolumn{2}{|c|}{ Log sales } & \multicolumn{2}{|c|}{ Log sales } \\
\hline Has adopted ISO 9001 & $\begin{array}{l}0.103 * * * \\
{[0.017]}\end{array}$ & & $\begin{array}{l}0.089 * * * \\
{[0.024]}\end{array}$ & & $\begin{array}{c}0.013 \\
{[0.023]}\end{array}$ & \\
\hline $\begin{array}{l}\text { Has adopted ISO } 9001 \\
\times \text { post-years } 1 / 2 / 3\end{array}$ & & $\begin{array}{l}0.061^{* * *} \\
{[0.018]}\end{array}$ & & $\begin{array}{c}0.040 \\
{[0.026]}\end{array}$ & & $\begin{array}{l}-0.020 \\
{[0.024]}\end{array}$ \\
\hline $\begin{array}{l}\text { Has adopted ISO } 9001 \\
\quad \times \text { post-years } 4 / 5 / 6\end{array}$ & & $\begin{array}{l}0.225 * * * \\
{[0.029]}\end{array}$ & & $\begin{array}{l}0.253 * * * \\
{[0.040]}\end{array}$ & & $\begin{array}{l}0.132 * * * \\
{[0.038]}\end{array}$ \\
\hline $\begin{array}{l}\text { Has adopted ISO } 9001 \\
\quad \times \text { post-years } 7 / 8 / 9\end{array}$ & & $\begin{array}{l}0.325^{* * *} \\
{[0.063]}\end{array}$ & & $\begin{array}{r}0.169^{*} \\
{[0.088]}\end{array}$ & & $\begin{array}{c}0.015 \\
{[0.084]}\end{array}$ \\
\hline Log payroll & & & & & $\begin{array}{l}0.432 * * * \\
{[0.015]}\end{array}$ & $\begin{array}{l}0.429 * * * \\
{[0.015]}\end{array}$ \\
\hline Constant & $\begin{array}{l}3.011 * * * \\
{[0.029]} \\
\end{array}$ & $\begin{array}{l}3.011 * * * \\
{[0.029]} \\
\end{array}$ & $\begin{array}{l}14.485 * * * \\
{[0.041]} \\
\end{array}$ & $\begin{array}{l}14.485 * * * \\
{[0.041]} \\
\end{array}$ & $\begin{array}{l}8.770 * * * \\
{[0.201]} \\
\end{array}$ & $\begin{array}{l}8.809 * * * \\
{[0.201]} \\
\end{array}$ \\
\hline Obs & 8420 & 8420 & 8420 & 8420 & 8420 & 8420 \\
\hline Firms & 94 & 9 & 94 & 9 & 942 & 94 \\
\hline R-squared & 0.23 & 0.23 & 0.25 & 0.2 & 0.33 & 0.33 \\
\hline Wald test ( & & $30.79 * * *$ & & $26.05^{* * *}$ & & $14.81 * * *$ \\
\hline Wald test $\left(\beta_{123}=\beta_{789}\right)$ & & $17.70 * * *$ & & 2.12 & & 0.18 \\
\hline Wald test $\left(\beta_{456}=\beta_{789}\right)$ & & 2.41 & & 0.87 & & 1.87 \\
\hline Wald test $\left(\beta_{123}=\beta_{456}=\beta_{789}\right)$ & & $20.55 * * *$ & & $13.15^{* * *}$ & & $7.46^{* * *}$ \\
\hline
\end{tabular}

Brackets contain standard errors. ${ }^{* *} \mathrm{p}<0.01, * * \mathrm{p}<5 \%, * \mathrm{p}<0.10$. All models estimated on the matched sample, using OLS. Additional controls include firm fixed effects, year dummies (1993-2003), and dummies denoting 9 years before through 9 years after the match year. Reported R-squares are withinfirm measures. Wald tests report $F$ statistics. 
Table 6.

\section{Employee outcomes}

\begin{tabular}{|c|c|c|c|c|c|c|c|c|c|c|c|c|c|c|}
\hline \multirow[b]{2}{*}{ Dependent variable: } & (1) & (2) & (3) & (4) & (5) & (6) & (7) & (8) & (9) & (10) & (11) & (12) & (13) & (14) \\
\hline & \multicolumn{2}{|c|}{ Log payroll } & \multicolumn{2}{|c|}{ Log payroll } & \multicolumn{2}{|c|}{ Log wages } & \multicolumn{2}{|c|}{ Log injury costs } & \multicolumn{2}{|c|}{ Log injury costs } & \multicolumn{2}{|c|}{ Injury rate } & \multicolumn{2}{|c|}{$\begin{array}{l}\text { Log average } \\
\text { occupational } \\
\text { riskiness } \\
\text { OLS }\end{array}$} \\
\hline Has adopted ISO 9001 & $\begin{array}{l}0.177^{* * *} \\
{[0.017]}\end{array}$ & & $\begin{array}{l}0.135^{* * *} \\
{[0.016]}\end{array}$ & & $\begin{array}{l}0.075^{* * *} \\
{[0.019]}\end{array}$ & & $\begin{array}{l}-0.016 \\
{[0.061]}\end{array}$ & & $\begin{array}{c}0.003 \\
{[0.050]}\end{array}$ & & \begin{tabular}{|l|}
-0.008 \\
{$[0.040]$}
\end{tabular} & & $\begin{array}{l}-0.047^{* * *} \\
{[0.009]}\end{array}$ & \\
\hline $\begin{array}{l}\text { Has adopted ISO } 9001 \\
\times \text { post-years } 1 / 2 / 3\end{array}$ & & $\begin{array}{l}0.142 * * * \\
{[0.019]}\end{array}$ & & $\begin{array}{c}0.117^{* * *} \\
{[0.017]}\end{array}$ & & $\begin{array}{l}0.081 * * * \\
{[0.020]}\end{array}$ & & $\begin{array}{l}-0.003 \\
{[0.066]}\end{array}$ & & $\begin{array}{c}0.020 \\
{[0.053]}\end{array}$ & & $\begin{array}{l}-0.035 \\
{[0.043]}\end{array}$ & & $\begin{array}{l}-0.044 * * * \\
{[0.010]}\end{array}$ \\
\hline $\begin{array}{c}\text { Has adopted ISO } 9001 \\
\times \text { post-years } 4 / 5 / 6\end{array}$ & & $\begin{array}{l}0.282^{* * *} \\
{[0.029]}\end{array}$ & & $\begin{array}{c}0.191 * * * \\
{[0.027]}\end{array}$ & & $\begin{array}{c}0.057^{*} \\
{[0.032]}\end{array}$ & & $\begin{array}{l}-0.066 \\
{[0.103]}\end{array}$ & & $\begin{array}{l}-0.039 \\
{[0.084]}\end{array}$ & & $\begin{array}{c}0.030 \\
{[0.062]}\end{array}$ & & $\begin{array}{l}-0.058^{* * *} \\
{[0.015]}\end{array}$ \\
\hline Has adopted ISO 9001 & & $\begin{array}{c}0.358^{* * *} \\
{[0.065]}\end{array}$ & & $0.226^{* * *}$ & & 0.033 & & 0.004 & & -0.188 & & $0.331 * *$ & & -0.024 \\
\hline $\begin{array}{l}\times \text { post-years } 7 / 8 / 9 \\
\text { Log injury rate }\end{array}$ & & {$[0.065]$} & & {$[0.060]$} & & {$[0.070]$} & & {$[0.226]$} & $\begin{array}{l}1.413 * * * \\
{[0.023]}\end{array}$ & $\begin{array}{c}{[0.184]} \\
1.413^{* * *} \\
{[0.023]}\end{array}$ & & [0.143] & & {$[0.033]$} \\
\hline Log employment & & & $\begin{array}{l}0.407 * * * \\
{[0.011]}\end{array}$ & $\begin{array}{l}0.405 * * * \\
{[0.011]}\end{array}$ & & & $\begin{array}{l}0.137 * * \\
{[0.055]}\end{array}$ & $\begin{array}{l}0.138^{* *} \\
{[0.055]}\end{array}$ & $\begin{array}{l}0.090^{* *} \\
{[0.045]}\end{array}$ & $\begin{array}{c}0.093 * * \\
{[0.045]}\end{array}$ & $\begin{array}{l}-0.036 \\
{[0.031]}\end{array}$ & $\begin{array}{l}-0.040 \\
{[0.031]}\end{array}$ & $\begin{array}{c}0.002 \\
{[0.007]}\end{array}$ & $\begin{array}{c}0.002 \\
{[0.007]}\end{array}$ \\
\hline Log payroll & & & & & & & $\begin{array}{l}0.604 * * * \\
{[0.044]}\end{array}$ & $\begin{array}{l}0.604 * * * \\
{[0.044]}\end{array}$ & $\begin{array}{l}-0.049 \\
{[0.037]}\end{array}$ & $\begin{array}{l}-0.048 \\
{[0.037]}\end{array}$ & $\begin{array}{l}0.916^{* * *} \\
{[0.030]}\end{array}$ & $\begin{array}{l}0.917^{* * *} \\
{[0.030]}\end{array}$ & $\begin{array}{l}-0.002 \\
{[0.006]}\end{array}$ & $\begin{array}{l}-0.002 \\
{[0.006]}\end{array}$ \\
\hline Log sales & & & & & & & $\begin{array}{l}-0.039 \\
{[0.038]}\end{array}$ & $\begin{array}{l}-0.038 \\
{[0.038]}\end{array}$ & $\begin{array}{l}0.000 \\
{[0.031]}\end{array}$ & $\begin{array}{c}0.000 \\
{[0.031]}\end{array}$ & $\begin{array}{l}-0.059 * * \\
{[0.024]}\end{array}$ & $\begin{array}{l}-0.057 * * \\
{[0.024]}\end{array}$ & & \\
\hline $\begin{array}{l}\text { Log average occupational } \\
\text { riskiness }\end{array}$ & & & & & & & $\begin{array}{l}0.233^{* * *} \\
{[0.079]}\end{array}$ & $\begin{array}{c}0.233 * * * \\
{[0.079]}\end{array}$ & $\begin{array}{c}0.017 \\
{[0.064]}\end{array}$ & $\begin{array}{c}0.017 \\
{[0.064]}\end{array}$ & $\begin{array}{c}0.384 * * * \\
{[0.062]}\end{array}$ & $\begin{array}{l}0.382 * * * \\
{[0.062]}\end{array}$ & & \\
\hline Constant & $\begin{array}{l}13.229 * * * \\
{[0.030]}\end{array}$ & $\begin{array}{l}13.229 * * * \\
{[0.030]}\end{array}$ & $\begin{array}{l}12.004 * * * \\
{[0.043]}\end{array}$ & $\begin{array}{l}12.011^{* * *} \\
{[0.043]}\end{array}$ & $\begin{array}{l}10.219 * * * \\
{[0.033]}\end{array}$ & $\begin{array}{l}10.219^{* * *} \\
{[0.033]}\end{array}$ & $\begin{array}{c}0.002 \\
{[0.688]}\end{array}$ & $\begin{array}{l}-0.016 \\
{[0.689]}\end{array}$ & $\begin{array}{l}7.049^{* * *} \\
{[0.571]}\end{array}$ & $\begin{array}{l}7.031 * * * \\
{[0.571]}\end{array}$ & $\begin{array}{l}-10.580^{* * *} \\
{[0.494]}\end{array}$ & $\begin{array}{c}-10.596^{* * *} \\
{[0.494]}\end{array}$ & $\begin{array}{l}0.863^{* * *} \\
{[0.081]}\end{array}$ & $\begin{array}{l}0.862^{* * *} \\
{[0.081]}\end{array}$ \\
\hline Observations & 8420 & 8420 & 8420 & 8420 & 8420 & 8420 & 8420 & 8420 & 8420 & 8420 & 6995 & 6995 & 8420 & 8420 \\
\hline Firms & 942 & 942 & 942 & 942 & 942 & 942 & 942 & 942 & 942 & 942 & 758 & 758 & 942 & 942 \\
\hline R-squared & 0.31 & 0.31 & 0.42 & 0.42 & 0.05 & 0.05 & 0.06 & 0.06 & 0.38 & 0.38 & & & 0.01 & 0.01 \\
\hline Wald test $\left(\beta_{123}=\beta_{456}\right)$ & & $20.99 * * *$ & & $6.80^{* * *}$ & & 0.55 & & 0.35 & & 0.47 & & 1.03 & & 0.81 \\
\hline Wald test $\left(\beta_{123}=\beta_{789}\right)$ & & $11.13 * * *$ & & $3.35^{*}$ & & 0.47 & & 0.00 & & 1.28 & & $6.53 * *$ & & 0.36 \\
\hline Wald test $\left(\beta_{456}=\beta_{789}\right)$ & & 1.32 & & 0.34 & & 0.11 & & 0.09 & & 0.63 & & $4.23 * *$ & & 1.01 \\
\hline Wald test $\left(\beta_{123}=\beta_{456}=\beta_{789}\right)$ & & $13.65^{* * *}$ & & $4.32 * *$ & & 0.43 & & 0.19 & & 0.75 & & $6.85^{* *}$ & & 0.71 \\
\hline
\end{tabular}

Brackets contain standard errors. $* * * \mathrm{p}<0.01, * * \mathrm{p}<5 \%, * \mathrm{p}<0.10$. Additional controls include firm fixed effects (conditional fixed effects for the negative binomial models), year dummies (1993-2003), and dummies denoting 9 years before through 9 years after the match year. Estimated for the matched sample. Reported R-squares are within firm measures. For Wald tests, F statistics are provided for OLS models and chi-squared statistics for the negative binomial model.

${ }^{a}$ The negative binomial model with conditional fixed effects is estimated only for firm-pairs in which both firms had at least one injury reported for worker's compensation during the sample period. 
Table 7.

Probability of reporting zero injuries for workers' compensation

\section{Dependent variable: Zero Injuries Reported for Workers' Compensation After Match Year (dummy)}

\begin{tabular}{lcc} 
& $\begin{array}{c}(1) \\
\text { Probit } \\
\text { coefficients }\end{array}$ & $\begin{array}{c}(2) \\
\text { Marginal } \\
\text { effects }\end{array}$ \\
\hline ISO 9001 adopter & $0.178^{*}$ & $0.051^{*}$ \\
Log employment (average after match) & {$[0.106]$} & {$[0.030]$} \\
& $-0.187^{* *}$ & $-0.053^{* *}$ \\
Log payroll (average after match) & {$[0.085]$} & {$[0.024]$} \\
& $-0.707^{* * *}$ & $-0.201^{* * *}$ \\
Constant & {$[0.085]$} & {$[0.024]$} \\
& $8.665^{* * *}$ & \\
\hline \hline Observations (firms) & {$[1.153]$} & \\
Pseudo R squared (McFadden's) & 942 & \\
Wald Chi squared & 0.32 & \\
\hline
\end{tabular}

Brackets contain standard errors. *** $\mathrm{p}<0.01, * * \mathrm{p}<5 \%, * \mathrm{p}<0.10$. The dependent variable is a dummy coded "1" for firms that reported no injuries for workers' compensation in all post-match years, and coded " 0 " for firms that reported one or more injuries. Employment and payroll variables are the log of each firm's average employment and payroll during all post-match years. Additional controls include 7 region dummies and 14 industry dummies. The sample is a cross section of all 471 pairs of matched adopters and non-adopters.

Table 8.

Outcomes: Smaller versus larger firms

\begin{tabular}{|c|c|c|c|c|c|c|}
\hline & $(1)$ & $(2)$ & $(3)$ & (4) & $(5)$ & (6) \\
\hline Dependent variable: & $\begin{array}{c}\text { Log } \\
\text { employment }\end{array}$ & Log sales & Log sales & $\begin{array}{c}\text { Log } \\
\text { payroll }\end{array}$ & $\begin{array}{c}\text { Log } \\
\text { payroll }\end{array}$ & $\begin{array}{c}\text { Log } \\
\text { wages }\end{array}$ \\
\hline $\begin{array}{l}\text { Has adopted ISO } 9001 \\
\times \text { above median employment (match year) }\end{array}$ & $\begin{array}{r}0.042^{*} \\
{[0.023]}\end{array}$ & $\begin{array}{l}-0.020 \\
{[0.032]}\end{array}$ & $\begin{array}{l}-0.074 * * \\
{[0.031]}\end{array}$ & $\begin{array}{l}0.114^{* * *} \\
{[0.024]}\end{array}$ & $\begin{array}{l}0.096^{* * *} \\
{[0.022]}\end{array}$ & $\begin{array}{l}0.072 * * * \\
{[0.026]}\end{array}$ \\
\hline $\begin{array}{l}\text { Has adopted ISO } 9001 \\
\times \text { below median employment (match year) }\end{array}$ & $\begin{array}{l}0.168^{* * *} \\
{[0.025]}\end{array}$ & $\begin{array}{l}0.210^{* * *} \\
{[0.034]}\end{array}$ & $\begin{array}{l}0.117 * * * \\
{[0.033]}\end{array}$ & $\begin{array}{l}0.247 * * * \\
{[0.025]}\end{array}$ & $\begin{array}{l}0.183^{* * *} \\
{[0.024]}\end{array}$ & $\begin{array}{l}0.079 * * * \\
{[0.028]}\end{array}$ \\
\hline $\begin{array}{l}\text { Log payroll } \\
\times \text { above median employment (match year) }\end{array}$ & & & $\begin{array}{l}0.474 * * * \\
{[0.022]}\end{array}$ & & & \\
\hline $\begin{array}{l}\text { Log payroll } \\
\quad \times \text { below median employment (match year) }\end{array}$ & & & $\begin{array}{l}0.378^{* * *} \\
{[0.021]}\end{array}$ & & & \\
\hline $\begin{array}{l}\text { Log employment } \\
\quad \times \text { above median employment (match year) }\end{array}$ & & & & & $\begin{array}{l}0.436^{* * *} \\
{[0.016]}\end{array}$ & \\
\hline $\begin{array}{l}\text { Log employment } \\
\times \text { below median employment (match year) }\end{array}$ & & & & & $\begin{array}{l}0.380^{* * *} \\
{[0.016]}\end{array}$ & \\
\hline Constant & $\begin{array}{l}3.021 * * * \\
{[0.029]}\end{array}$ & $\begin{array}{l}14.490 * * * \\
{[0.041]}\end{array}$ & $\begin{array}{l}8.793 * * * \\
{[0.203]}\end{array}$ & $\begin{array}{l}13.228^{* * *} \\
{[0.030]}\end{array}$ & $\begin{array}{l}11.976^{* * * *} \\
{[0.044]}\end{array}$ & $\begin{array}{l}10.206 * * * \\
{[0.033]}\end{array}$ \\
\hline Observations & 8420 & 8420 & 8420 & 8420 & 8420 & 8420 \\
\hline Firms & 942 & 942 & 942 & 942 & 942 & 942 \\
\hline $\begin{array}{l}\text { R-squared } \\
\text { Wald test: }\end{array}$ & 0.25 & 0.26 & 0.34 & 0.32 & 0.43 & 0.06 \\
\hline$\beta_{\text {has adopted } \mathrm{x} \text { above median }}=\beta_{\text {has adopted } \mathrm{x} \text { below median }}$ & $14.11 * * *$ & $23.77 * * *$ & $17.87 * * *$ & $14.57 * * *$ & $7.39 * * *$ & 0.03 \\
\hline
\end{tabular}

Brackets contain standard errors. $* * * \mathrm{p}<0.01, * * \mathrm{p}<5 \%, * \mathrm{p}<0.10$. Additional controls include firm fixed effects (conditional fixed effects for the negative binomial models), year dummies (1993-2003), and dummies denoting 9 years before through 9 years after the match year. Estimated for the matched sample. Reported R-squares are within firm measures. All models estimated using OLS. Wald tests report F statistics. 


\section{On-line Appendix (e-companion)}

Table A1.

Description and summary statistics of variables used to generate propensity scores for the matching process (in addition to those in the paper's Table 2)

\begin{tabular}{|c|c|c|c|c|c|}
\hline Variable & Description & Mean & SD & Min & Max \\
\hline $\begin{array}{l}\text { Adopts ISO } 9001 \\
\text { this year (dummy) }\end{array}$ & Dummy coded " 1 " if the firm adopted ISO 9001 this year, and " 0 " otherwise. & 0.006 & 0.08 & 0 & 1 \\
\hline Injury costs $_{-1 \&-2}$ & $\begin{array}{l}\text { Average of the one- and two-year lags of total annual workers' compensation injury costs, in } \\
\text { thousands of dollars. }{ }^{\text {a }}\end{array}$ & 7.95 & 112.88 & 0 & $27,765.74$ \\
\hline $\begin{array}{l}\text { Injury costs-1\&-2, } \\
\text { squared }\end{array}$ & Square of injury costs $-1 \&-2$, reported in billions of dollars. & 12.80 & $2,606.84$ & 0 & $770,936.30$ \\
\hline Injury rate $-1 \&-2$ & $\begin{array}{l}\text { Average of one- and two-year lags of annual number of injuries reported for workers' } \\
\text { compensation. }\end{array}$ & 1.08 & 18.78 & 0 & $4,149.00$ \\
\hline $\begin{array}{l}\text { Injury rate }_{-1 \&-2,} \\
\text { squared }\end{array}$ & Square of injury rate ${ }_{-1 \&-2}$, reported in thousands of injuries. & 0.35 & 69.83 & 0 & $17,214.20$ \\
\hline No injuries $-1 \&-2$ & Dummy coded " 1 " if the firm reported no injuries in the prior two years, and " 0 " otherwise. & 0.64 & 0.48 & 0 & 1 \\
\hline Payroll $-1 \&-2_{-2}$ & Average of one- and two-year lags of annual payroll, in millions of dollars. ${ }^{\mathrm{b}, \mathrm{c}}$ & 0.54 & 8.59 & 0.01 & $2,182.77$ \\
\hline Payroll $_{-1 \&-2}$, squared & Square of payroll $-1 \&-2$, reported in trillions of dollars. & 74.06 & $16,170.04$ & 0.00 & $4,764,504$ \\
\hline Employment $-1 \&-2$ & Average of one- and two-year lags of employees. ${ }^{c}$ & 14.21 & 25.23 & 1 & 1800 \\
\hline $\begin{array}{l}\text { Employment }-1 \&-2, \\
\text { squared }\end{array}$ & Square of employment $-1 \&-2$, reported in thousands of employees. ${ }^{c}$ & 0.84 & 14.32 & 0.001 & 3240 \\
\hline Wage $_{-1 \&-2}$ & Average of one- and two-year lags of payroll/employment, reported in thousands of dollars. ${ }^{\mathrm{d}}$ & 44.89 & 254.30 & 7.02 & $53,989.38$ \\
\hline Log wage $_{-1 \&-2}$ & 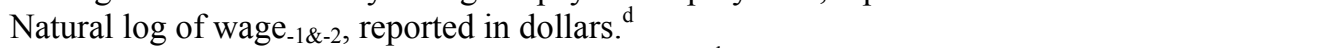 & 10.21 & 0.78 & 8.86 & 17.80 \\
\hline Wage $_{-1 \&-2}$, squared & Square of wage $_{-1 \&-2,}$, reported in trillions of dollars. ${ }^{\mathrm{d}}$ & 0.07 & 10.92 & 0.00 & $2,914.85$ \\
\hline Sales$_{-1 \&-2}$ & Average of one- and two-year lags of annual firm sales, reported in millions of dollars. & 2.15 & 5.54 & 0.00 & 329.35 \\
\hline 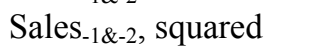 & Square of sales $_{-1 \&-2}$, reported in quadrillions of dollars. & 0.04 & 0.76 & 0.00 & 108.47 \\
\hline $\begin{array}{l}\text { Average } \\
\text { occupational } \\
\text { riskiness }-1 \&-2\end{array}$ & $\begin{array}{l}\text { Firm's average annual hazard per payroll dollar. A firm's annual average hazard is the sum } \\
\text { across all occupation classes of the following: the payroll dollars in each occupation class } \\
\text { multiplied by the WCIRB Pure Premium Rate for each occupation class. We divide this by the } \\
\text { firm's payroll that year. }\end{array}$ & 2.24 & 1.74 & 0.18 & 22.73 \\
\hline $\begin{array}{l}\text { Average } \\
\text { occupational } \\
\text { riskiness-1\&-2,squared }\end{array}$ & Square of average occupational riskiness ${ }_{-1 \&-2}$. & 8.08 & 12.57 & 0.032 & 516.65 \\
\hline \multicolumn{6}{|c|}{$\begin{array}{l}\mathrm{N}=143,580 \text { firm-year observations. Sample includes all non-adopters, and adopters before and in their adoption year, provided they have observations with complete data for the model. } \\
\text { a Missing values for injury costs are converted to zeros if data exists for exposure in that year. If one of the two lags is missing, the average will equal the non-missing lag. } \\
\text { b To minimize the impact of outliers, we omitted very small annual payroll values (less than } \$ 5,000 \text { ). } \\
\text { c To minimize the impact of firms that were rapidly growing or shrinking, we omitted instances in which the ratio of the current year's value to its one-year lag was outside the range of } 0.5 \\
\text { to } 2 \text {. } \\
\text { do minimize the impact of outliers, we omitted firm-years with very low average annual wages (less than } \$ 7,020 \text {, calculated as } 20 \text { hours per week * } 52 \text { weeks per year * } \$ 6.75 \text { [California } \\
\text { minimum wage as of Jan } 2002] \text { ). }\end{array}$} \\
\hline
\end{tabular}


Table A2.

Probit results that generated propensity scores

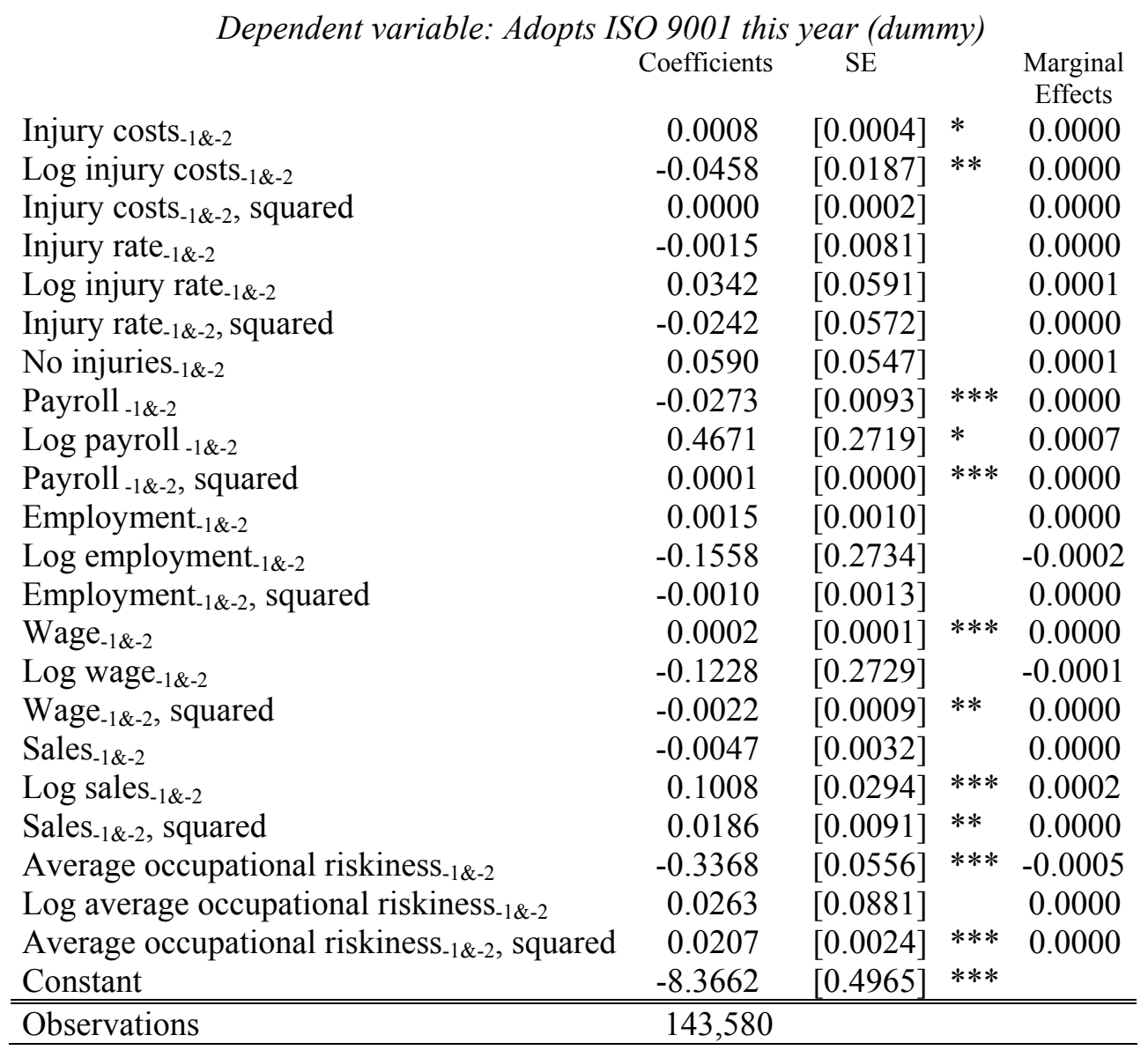

Brackets contain robust standard errors clustered by firm. $* * * p<0.01, * * p<5 \%, * p<0.10$. Additional controls include year dummies (1995-2005), 7 region dummies, and 14 industry dummies. Sample includes adopters before and in their adoption year, and non-adopters in all years. 
Table A3.

\section{Assessing the quality of the matched sample for the treatment analysis}

\section{Balancing test results}

\begin{tabular}{|c|c|c|c|c|c|c|c|c|}
\hline \multirow[t]{2}{*}{ Variable } & \multicolumn{3}{|c|}{$\begin{array}{l}\text { Matched } \\
\text { non-adopters }\end{array}$} & \multicolumn{3}{|c|}{$\begin{array}{l}\text { Matched } \\
\text { adopters }\end{array}$} & \multirow{2}{*}{\multicolumn{2}{|c|}{$\begin{array}{c}\text { t-test } \\
\text { p-value }\end{array}$}} \\
\hline & $\mathrm{N}$ & Mean & SE & $\mathrm{N}$ & Mean & $\mathrm{SE}$ & & \\
\hline${\text { Log injury } \text { costs }_{-1 \&-2}}$ & 471 & 8.23 & 0.074 & 471 & 8.44 & 0.077 & 0.06 & \\
\hline Percent change $\mathrm{e}^{\mathrm{a}}$ in ratio of injury costs & 268 & -0.04 & 0.093 & 268 & 0.25 & 0.088 & 0.03 & $* *$ \\
\hline $\log _{\text {injury }}$ costs $_{-1 \&-2}-\log$ injury costs $-3 \&-4$ & 381 & 0.04 & 0.079 & 381 & 0.20 & 0.072 & 0.12 & \\
\hline Log injury rate $-1 \&-2$ & 471 & 0.90 & 0.042 & 471 & 0.98 & 0.045 & 0.20 & \\
\hline Percent change $\mathrm{e}^{\mathrm{a}}$ in ratio of injury rate & 268 & -0.04 & 0.076 & 268 & 0.16 & 0.069 & 0.06 & $*$ \\
\hline $\log _{\text {injury rate }}-1 \&-2-\log$ injury rate $-3 \&-4$ & 381 & 0.02 & 0.030 & 381 & 0.06 & 0.028 & 0.36 & \\
\hline Log payroll $_{-1 \&-2}$ & 471 & 13.64 & 0.043 & 471 & 13.76 & 0.049 & 0.06 & * \\
\hline Percent change ${ }^{\mathrm{a}}$ in ratio of payroll & 364 & 0.25 & 0.018 & 364 & 0.23 & 0.019 & 0.55 & \\
\hline Log payroll $_{-1 \&-2}-\log$ payroll $_{-3 \&-4}$ & 364 & 0.28 & 0.024 & 364 & 0.26 & 0.023 & 0.54 & \\
\hline Log employment $1 \&-2$ & 471 & 3.14 & 0.045 & 471 & 3.21 & 0.048 & 0.30 & \\
\hline Percent change $\mathrm{e}^{\mathrm{a}}$ in ratio of employment & 431 & 0.12 & 0.018 & 431 & 0.15 & 0.016 & 0.24 & \\
\hline Log employment $_{-1 \&-2}-\log$ employment $-3 \&-4$ & 431 & 0.13 & 0.022 & 431 & 0.16 & 0.018 & 0.42 & \\
\hline Log $_{\text {wages }} 1 \&-2$ & 471 & 10.50 & 0.033 & 471 & 10.55 & 0.040 & 0.27 & \\
\hline Percent change ${ }^{a}$ in ratio of wages & 328 & 0.08 & 0.022 & 328 & 0.05 & 0.022 & 0.30 & \\
\hline Log wages $_{-1 \&-2}-\log$ wages $_{-3 \&-4}$ & 328 & 0.07 & 0.025 & 328 & 0.05 & 0.024 & 0.45 & \\
\hline Log sales $-1 \&-2$ & 471 & 14.85 & 0.049 & 471 & 14.88 & 0.053 & 0.72 & \\
\hline Percent change ${ }^{\mathrm{a}}$ in ratio of sales & 431 & 0.20 & 0.019 & 431 & 0.21 & 0.019 & 0.71 & \\
\hline Log sales $_{-1 \&-2}-\log$ sales $_{-3 \&-4}$ & 431 & 0.23 & 0.026 & 431 & 0.22 & 0.026 & 0.64 & \\
\hline Log average occupational riskiness ${ }_{-1 \&-2}$ & 471 & 0.74 & 0.029 & 471 & 0.76 & 0.029 & 0.58 & \\
\hline $\begin{array}{l}\text { Percent change in ratio of average } \\
\text { occupational riskiness }\end{array}$ & 364 & -0.01 & 0.009 & 364 & 0.00 & 0.011 & 0.28 & \\
\hline $\begin{array}{l}\text { Log average occupational riskiness }-1 \&-2 \\
-\log \text { average occupational riskiness }-3 \&-4\end{array}$ & 364 & -0.01 & 0.009 & 364 & 0.00 & 0.012 & 0.27 & \\
\hline
\end{tabular}

$* * * \mathrm{p}<0.01, * * \mathrm{p}<5 \%,{ }^{*} \mathrm{p}<0.10$.

Variables subscripted $-1 \&-2$ are averages of 1- and 2- year lags, and $-3 \&-4$ are averages of 3- and 4-year lags.

a "Percent change" variables are constructed as the difference in the average value of the 3-and 4-year lagged values from the average value of the 1- and 2-year lagged values, divided by half the sum these values. This ratio approximates "percent change," but is robust to outliers; it ranges from -2 to +2 .

${ }^{\mathrm{b}}$ Wages are the ratio of payroll to employment. To minimize the impact of outliers, we omitted firm-years with very low average annual wages (less than $\$ 7,020$, calculated as 20 hours per week $* 52$ weeks per year $* \$ 6.75$ [California minimum wage as of Jan 2002]). 
Table A4.

Survival analysis: Regression results

Dependent variable: Firm survival

\begin{tabular}{|c|c|c|c|c|c|c|}
\hline & \multicolumn{3}{|c|}{ (1) } & \multicolumn{2}{|c|}{ (2) } & \multirow{2}{*}{$\begin{array}{c}(3) \\
\text { Stratified Cox } \\
\text { proportional hazards } \\
\text { model }\end{array}$} \\
\hline & \multicolumn{3}{|c|}{$\begin{array}{l}\text { Cross-sectional } \\
\text { logistic model }\end{array}$} & \multicolumn{2}{|c|}{$\begin{array}{c}\text { Conditional fixed effects } \\
\text { logistic model }\end{array}$} & \\
\hline & Coefficients & $\begin{array}{l}\text { Marginal } \\
\text { effects }\end{array}$ & Odds ratios & Coefficients & Odds ratios & Hazard ratio \\
\hline Adopter & $\begin{array}{l}2.842 * * * \\
{[0.605]}\end{array}$ & $\begin{array}{l}0.045^{* * *} \\
{[0.010]}\end{array}$ & $\begin{array}{l}17.156^{* * *} \\
{[10.374]}\end{array}$ & $\begin{array}{l}3.055 * * * \\
{[0.853]}\end{array}$ & $\begin{array}{l}21.224 * * * \\
{[18.095]}\end{array}$ & $\begin{array}{l}0.047 * * * \\
{[0.040]}\end{array}$ \\
\hline Log employment $t-1 \& t-2$ & $\begin{array}{c}0.127 \\
{[0.268]}\end{array}$ & $\begin{array}{c}0.002 \\
{[0.003]}\end{array}$ & $\begin{array}{c}1.135 \\
{[0.304]}\end{array}$ & $\begin{array}{l}-0.067 \\
{[0.974]}\end{array}$ & $\begin{array}{c}0.935 \\
{[0.911]}\end{array}$ & $\begin{array}{c}1.069 \\
{[1.042]}\end{array}$ \\
\hline Log payroll $\mathrm{t}-1 \& \mathrm{t}-2$ & $\begin{array}{l}-0.059 \\
{[0.229]}\end{array}$ & $\begin{array}{l}-0.001 \\
{[0.003]}\end{array}$ & $\begin{array}{c}0.943 \\
{[0.216]}\end{array}$ & $\begin{array}{c}1.830 \\
{[1.688]}\end{array}$ & $\begin{array}{c}6.236 \\
{[10.527]}\end{array}$ & $\begin{array}{c}0.160 \\
{[0.271]}\end{array}$ \\
\hline Log sales $t-1 \& t-2$ & $\begin{array}{l}-0.415 * * \\
{[0.201]}\end{array}$ & $\begin{array}{l}-0.005^{*} \\
{[0.003]}\end{array}$ & $\begin{array}{l}0.660^{* *} \\
{[0.133]}\end{array}$ & $\begin{array}{l}-0.096 \\
{[0.530]}\end{array}$ & $\begin{array}{c}0.908 \\
{[0.481]}\end{array}$ & $\begin{array}{c}1.101 \\
{[0.583]}\end{array}$ \\
\hline Log average occupational riskiness $\mathrm{t}_{\mathrm{t}-1 \mathrm{kt}-2}$ & $\begin{array}{l}1.302^{* * *} \\
{[0.383]}\end{array}$ & $\begin{array}{l}0.016^{* * *} \\
{[0.006]}\end{array}$ & $\begin{array}{l}3.678^{* * *} \\
{[1.409]}\end{array}$ & $\begin{array}{l}-0.965 \\
{[2.523]}\end{array}$ & $\begin{array}{c}0.381 \\
{[0.961]}\end{array}$ & $\begin{array}{c}2.624 \\
{[6.621]}\end{array}$ \\
\hline Region dummies & Included & Included & Included & Absorbed & Absorbed & Absorbed \\
\hline Industry dummies & Included & Included & Included & Absorbed & Absorbed & Absorbed \\
\hline $\begin{array}{l}\text { Conditional fixed effects for } \\
\text { (stratified by) matched groups }\end{array}$ & & & & Included & Included & \\
\hline Constant & $\begin{array}{l}10.609 * * * \\
{[3.969]}\end{array}$ & & & & & \\
\hline Observations & & 1,244 firms & & $94 \mathrm{fir}$ & irms & 5,040 firm-years \\
\hline
\end{tabular}

In these models, all independent variables are time-invariant, calculated as the log of average values over the two years prior to the match (adoption) year. Model 1 is cross-sectional, estimated on one observation per firm. Model 2 is also cross-sectional, but stratified (grouped) by each match group (i.e., an adopting firm and its control firm). It drops all match groups in which both members survive through 2003 (when our sample is right censored), and is thus estimated only on match groups in which one or both members of the match group dies. Model 3 is a survival model
estimated
on
firm-years,
and
is also
stratified
(grouped)
by
match
groups. 


\section{Table A5. \\ Balancing tests: Financial stress}

Panel A.

T-tests indicate that the matched samples are balanced on the PAYDEX indicator of financial stress

\begin{tabular}{|c|c|c|c|c|}
\hline Matched sample & $\begin{array}{l}\text { Firm's financial stress } \\
\text { indicator in the match year }\end{array}$ & $\begin{array}{c}\text { Matched } \\
\text { controls: } \\
\text { Mean } \\
\{\mathrm{SD}\} \\
{[\mathrm{SE}]}\end{array}$ & $\begin{array}{c}\text { Matched } \\
\text { adopters: } \\
\text { Mean } \\
\{\mathrm{SD}\} \\
{[\mathrm{SE}]}\end{array}$ & $\begin{array}{l}\text { t-test } \\
\text { p-value }\end{array}$ \\
\hline \multirow[t]{2}{*}{$\begin{array}{l}\text { Matched sample for } \\
\text { treatment analysis }\end{array}$} & Minimum PAYDEX score & $\begin{array}{c}68.54 \\
\{10.42\} \\
{[0.51]}\end{array}$ & $\begin{array}{l}67.59 \\
\{9.88\} \\
{[0.48]} \\
\end{array}$ & 0.18 \\
\hline & Maximum PAYDEX score & $\begin{array}{l}75.49 \\
\{6.68\} \\
{[0.33]} \\
\end{array}$ & $\begin{array}{l}75.41 \\
\{6.08\} \\
{[0.30]} \\
\end{array}$ & 0.85 \\
\hline \multirow[t]{2}{*}{$\begin{array}{l}\text { Matched sample for } \\
\text { survival analysis }\end{array}$} & Minimum PAYDEX score & $\begin{array}{c}68.23 \\
\{10.98\} \\
{[0.48]}\end{array}$ & $\begin{array}{c}67.36 \\
\{10.21\} \\
{[0.44]}\end{array}$ & 0.18 \\
\hline & Maximum PAYDEX score & $\begin{array}{l}75.43 \\
\{7.25\} \\
{[0.31]}\end{array}$ & $\begin{array}{l}75.21 \\
\{6.25\} \\
{[0.27]}\end{array}$ & 0.59 \\
\hline
\end{tabular}

Note: These t-tests compared PAYDEX values in the match year between 415 matched controls to 419 adopters for the treatment analysis, and 533 matched controls to 546 adopters for the survival analysis. The somewhat smaller number of firms than our full matched sample and slight imbalance between adopters and controls in this analysis are due to gaps in the PAYDEX data. $\mathrm{SD}=$ standard deviation; $\mathrm{SE}=$ standard error.

Panel B.

Wilcoxon rank-sum tests indicate that the matched samples are balanced on the D\&B Composite Credit Appraisal indicator of financial stress

\begin{tabular}{|l|l|c|c|c|}
\hline Matched sample & $\begin{array}{l}\text { Firm's financial stress } \\
\text { indicator in the match year }\end{array}$ & $\begin{array}{c}\text { Matched } \\
\text { controls: } \\
\text { Mean } \\
\{\mathrm{SD}\}\end{array}$ & $\begin{array}{c}\text { Matched } \\
\text { adopters: } \\
\text { Mean } \\
\{\mathrm{SD}\}\end{array}$ & $\begin{array}{c}\text { Wilcoxon } \\
\text { rank-sum } \\
\text { p-value }\end{array}$ \\
\hline $\begin{array}{l}\text { Matched sample for } \\
\text { treatment analysis }\end{array}$ & Composite Credit Appraisal & $\begin{array}{c}2.52 \\
\{0.78\}\end{array}$ & $\begin{array}{c}2.51 \\
\{0.78\}\end{array}$ & 0.80 \\
\hline $\begin{array}{l}\text { Matched sample for } \\
\text { survival analysis }\end{array}$ & Composite Credit Appraisal & $\begin{array}{c}2.49 \\
\{0.80\}\end{array}$ & $\begin{array}{c}2.48 \\
\{0.77\}\end{array}$ & 0.76 \\
\hline
\end{tabular}

Note: This table reports results of Wilcoxon rank-sum tests of the D\&B Composite Credit Appraisal score, an ordinal variable that we reverse coded so that higher values correspond to more credit worthiness $(1=$ Limited; 2=Fair; 3=Good; $4=$ High). These rank-sum tests compared Composite Credit Appraisal scores in the match year of 355 matched controls to 343 adopters for the treatment analysis, and 445 matched controls to 457 adopters for the survival analysis. The somewhat smaller number of firms than our full matched sample and slight imbalance between adopters and controls in this analysis are due to gaps in the D\&B Composite Credit Appraisal data. SD = standard deviation. 


\section{Table A6. \\ Robustness tests: Financial stress}

Predicting adoption of ISO 9001 including various indicators of financial stress

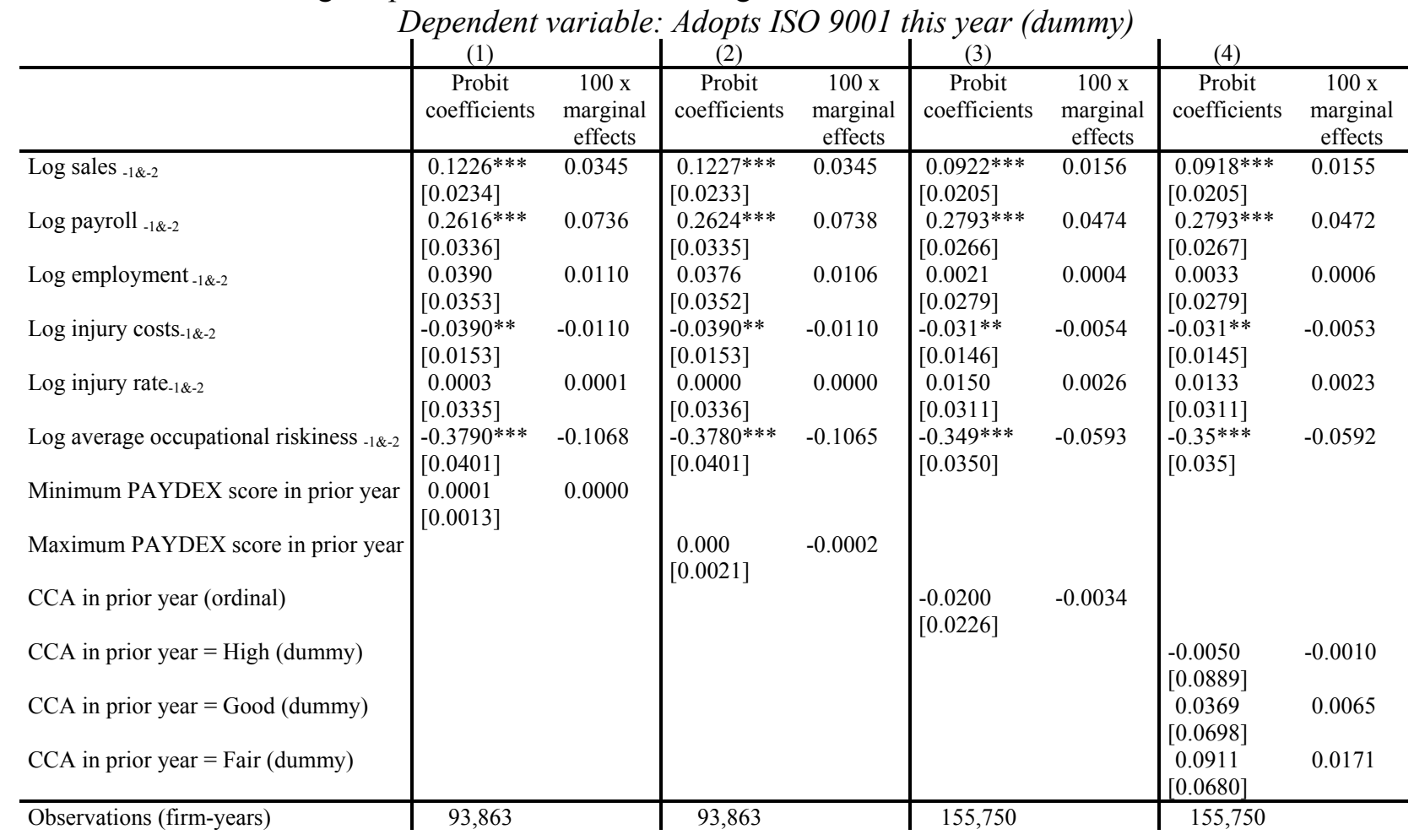

$\mathrm{CCA}=$ Composite Credit Appraisal. Brackets contain robust standard errors clustered by firm. $* * * \mathrm{p}<0.01, * * \mathrm{p}<5 \%, * \mathrm{p}<0.10$. Variables subscripted $-1 \&-2$ are averages of 1- and 2- year lags. Additional controls include year dummies (1995-2005), 7 region dummies, and 14 industry dummies. The ordinal measure of CCA used in Model 3 is inverted so that higher values correspond to greater credit worthiness. Models 3 and 4 also include a dummy indicating when missing values of D\&B Composite Credit Appraisal were recoded to 0 . Sample includes adopters before and in their adoption year and all years for non-adopters. 